\title{
New Linear Lipopeptides Produced by Pseudomonas cichorii SF1-54 Are Involved in Virulence, Swarming Motility, and Biofilm Formation
}

\author{
Ellen Pauwelyn, ${ }^{1,2}$ Chien-Jui Huang, ${ }^{1}$ Marc Ongena, ${ }^{3}$ Valérie Leclère, ${ }^{4}$ Philippe Jacques, ${ }^{4}$ Peter Bleyaert, ${ }^{2}$ \\ Herbert Budzikiewicz, ${ }^{5}$ Mathias Schäfer, ${ }^{5}$ and Monica Höfte ${ }^{1}$ \\ ${ }^{1}$ Department of Crop Protection, Laboratory of Phytopathology, Ghent University, Coupure Links 653, 9000 Ghent, Belgium; \\ ${ }^{2}$ Inagro vzw, leperseweg 87, 8800 Rumbeke, Belgium; ${ }^{3}$ Walloon Centre for Industrial Biology, University of Liège-Gembloux \\ Agro-Bio Tech, Passage des Déportés 2, 5030 Gembloux, Belgium; ${ }^{4}$ Laboratoire de Procédés Biologiques, Génie \\ Enzymatique et Microbien (ProBioGEM), Université de Lille Sciences et Technologies, F-59655 Villeneuve d'Ascq Cedex, \\ France; ${ }^{5}$ Institut für Organische Chemie, Universität zu Köln, Greinstr. 4, 50939 Köln, Germany
}

Submitted 2 November 2012. Accepted 5 February 2013.

Pseudomonas cichorii is the causal agent of lettuce midrib rot, characterized by a dark-brown to green-black discoloration of the midrib. Formation of necrotic lesions by several plant-pathogenic pseudomonads is associated with production of phytotoxic lipopeptides, which contribute to virulence. Therefore, the ability of $P$. cichorii SF1-54 to produce lipopeptides was investigated. A cell-free culture filtrate of SF1-54 showed surfactant, antimicrobial, and phytotoxic activities which are typical for lipopeptides. High-performance liquid chromatography analysis of $P$. cichorii SF1-54 culture filtrate revealed the presence of seven compounds with lipopeptide characteristics. Two related lipopeptides, named cichofactin A and B, were studied in more detail: they are linear lipopeptides with a decanoic and dodecanoic lipid chain, respectively, connected to the N-terminus of an eight-amino-acid peptide moiety. Both cichofactins are new members of the syringafactin lipopeptide family. Furthermore, two nonribosomal peptide synthethase-encoding genes, $\operatorname{cif} A$ and $\operatorname{cif} B$, were identified as responsible for cichofactin biosynthesis. A cifAB deletion mutant no longer produced cichofactins and was impaired in swarming motility but showed enhanced biofilm formation. Upon spray inoculation on lettuce, the cichofactindeficient mutant caused significantly less rotten midribs than the wild type, indicating that cichofactins are involved in pathogenicity of $P$. cichorii SF1-54. Further analysis revealed that $\boldsymbol{P}$. cichorii isolates vary greatly in swarming motility and cichofactin production.

Many plant-pathogenic bacteria are known to produce nonhost-specific phytotoxins that contribute to virulence (Kunkel and Zhongying 2006). Well-characterized phytotoxins are those produced by Pseudomonas syringae and include chlorosisinducing toxins (e.g., coronatine, phaseolotoxin, and tabtoxin) and necrosis-inducing toxins (e.g., syringomycin and syringopeptin) (Bender et al. 1999). The latter are cyclic lipopeptides

Corresponding author: Monica Höfte; E-mail: monica.hofte@ugent.be

* The $\boldsymbol{e}$-Xtra logo stands for "electronic extra" and indicates that four supplementary figures and three supplementary tables are published online.

C 2013 The American Phytopathological Society
(CLP), which are amphipathic molecules composed of a fatty acid tail linked to a cyclic oligopeptide head. Due to this amphipatic nature, they can insert into the plasma membrane of their host cells, which is their primary target, and form pores. This results in transmembrane fluxes of $\mathrm{H}^{+}, \mathrm{Ca}^{2+}$, and $\mathrm{K}^{+}$and leads to a collapse of the $\mathrm{pH}$ gradient across the plasma membrane, consequently resulting in cell death. This process is highly efficient, because only a few nanomoles of toxin suffice to induce pore formation (Bender and Scholz-Schroeder 2004; Bender et al. 1999). In addition to phytotoxicity, these CLP toxins also exhibit hemolytic and antimicrobial activity (Hutchison and Gross 1997; Hutchison et al. 1995; Lavermicocca et al. 1997). This latter feature of lipopeptides has been exploited by researchers to develop bioassays that have expedited detection of lipopeptide production, purification, and genetic studies on these cyclic lipopeptides.

However, lipopeptides are not always phytotoxic. Depending on their structure, they may have diverse other roles and functions and can be involved in swarming motility, biofilm development, and colonization, or display zoosporicidal or antimicrobial activity (Raaijmakers et al. 2006, 2010). These functions are extensively described for antagonistic Pseudomonas spp. but to a lesser extent for plant-pathogenic pseudomonads. The only available examples to date are the syringafactins, which are essential for swarming motility of $P$. syringae pv. tomato DC3000 and P. syringae pv. syringae B728a (Berti et al. 2007; Burch et al. 2010) and viscosin, which is required for $P$. fluorescens 5064 to colonize the surface of broccoli florets (Hildebrand et al. 1998).

$P$. cichorii is an important plant-pathogenic bacterium, with a wide host range and a worldwide distribution. $P$. cichorii causes necrotic leaf and stem lesions on vegetables, ornamentals, cereals, and woody plants (Bradbury 1986). Economically important hosts include lettuce, celery, chrysanthemum, tomato, coffee, and soybean (Bradbury 1986; Jagger 1914; Jones et al. 1984; Wilk and Dye 1974; Yu and Lee 2012). In Belgian greenhouse-grown butterhead lettuce, $P$. cichorii causes a darkbrown to green-black discoloration of the midrib (Cottyn et al. 2009, 2011; Pauwelyn et al. 2011). Symptom development on lettuce leaves is strongly associated with apoptosis-like programmed cell death (Kiba et al. 2006, 2009). Intriguingly, the type III secretion system is essential for pathogenicity of P. cichorii on eggplant but not on lettuce (Hojo et al. 2008; Kajihara et al. 2012). Symptom development may be associ- 
ated with the production of necrosis-inducing cyclic lipopeptide toxins by this bacterium. The production of antimicrobial and phytotoxic substances by $P$. cichorii has already been described (Hikichi et al. 1998; Hu et al. 1998; Lazzaroni et al. 2003) but no bioactive compound has been characterized to date.

Therefore, the aim of this study was to examine the ability of $P$. cichorii to produce phytotoxic and antimicrobial compounds using bioassays. Seven bioactive compounds produced in culture by the highly virulent $P$. cichorii SF1-54 were isolated and partly characterized by reverse-phase high-performance liquid chromatography (RP-HPLC) and liquid chromatography electrospray ionization mass spectrometry (LC-ESI-MS). The structures of two of these lipopeptides produced by $P$. cichorii SF1-54 were elucidated using LC-ESI-MS and high-resolution (HR)-ESI tandem mass spectrometry (MS-MS). They appear to be linear lipopeptides, consisting of eight amino acids, and are novel members of the syringafactin family of lipopeptides. In addition, genome mining of $P$. cichorii SF1-54 revealed two nonribosomal peptide synthetase (NRPS) genes, cifA and cifB, that encode the lipopeptide synthetases responsible for biosynthesis of cichofactins. Based on the cifA and cifB gene sequences, a cichofactin-deficient mutant was constructed to investigate the function of these compounds for $P$. cichorii SF1-54.

\section{RESULTS}

\section{Biological activity of strain SF1-54 and its secreted metabolites.}

Injection of a $P$. cichorii SF1-54 bacterial suspension $(1 \times$ $10^{8} \mathrm{CFU} / \mathrm{ml}$ ) into lettuce or chicory leaves resulted in brown lesions in the treated area within $24 \mathrm{~h}$ postinoculation (Fig. 1A). Injection of a crude culture filtrate of $P$. cichorii SF1-54 caused identical symptoms (Fig. 1B), suggesting that a phytotoxic compound is produced and secreted into the $\mathrm{SRM}_{\mathrm{AF}}$ medium (Gross 1985). No symptom was visible by injection of noninoculated medium in chicory. Although minor rotting symptoms were often observed on the lettuce leaves of the noninoculated treatments, they looked clearly different from the symptoms caused by $P$. cichorii SF1-54 and its crude culture filtrate, indicating that they are possibly due to wounding, contamination, or senescence (Fig. 1C).

Symptom development is similar in lettuce and chicory leaves; therefore, only chicory leaves were used for further phytotoxicity tests, because they are less prone to contamination and easier to handle for reproducible infection.

P. cichorii SF1-54 inhibited growth of Bacillus megaterium (a bacterium), Geotrichum candidum (a filamentous fungus), and Rhodotorula mucilaginosa (a yeast). The indicator microorganisms were selected according to the spectrum of antimicrobial activities of $P$. syringae pv. syringae toxins (Lavermicocca et al. 1997). In direct antagonistic assays against these microorganisms, a $P$. cichorii SF1-54 colony produced inhibition zones of 25 to $41 \mathrm{~mm}$ against $B$. megaterium, 38 to $53 \mathrm{~mm}$ against $G$. candidum, and 50 to $56 \mathrm{~mm}$ against $R$. mucilaginosa under our experimental conditions. The crude culture filtrate and semipurified culture extract (solid-phase extraction on $\mathrm{C} 18$ cartridge) retained these inhibitory capacities against $B$. megaterium, $G$. candidum, and $R$. mucilaginosa (Fig. 2B).

The active molecules produced by strain SF1-54 in $\mathrm{SRM}_{\mathrm{AF}}$ medium were isolated from the semipurified culture extracts by repeated injections in semipreparative RP-HPLC. Repeated injections were performed on a protein and peptide C-18 column. The eluates were monitored spectrophotometrically at $220 \mathrm{~nm}$. All eluates absorbing at $220 \mathrm{~nm}$ were independently collected in 23 fractions, corresponding to the observed peaks in the RP-HPLC chromatogram (Fig. 2A). All fractions were first tested for surfactant activity and seven compounds (Fig. $2 \mathrm{~A}$, letters A to G) caused drop collapse, which is characteristic of biosurfactant metabolites.

Antimicrobial activity and phytotoxicity of these purified molecules were then assayed (Fig. 2B). Compound A inhibited the growth of B. megaterium. Compound B had antimicrobial activity against $G$. candidum and $R$. mucilaginosa, while compound $\mathrm{C}$ only inhibited $R$. mucilaginosa. Compounds $\mathrm{D}$ and $\mathrm{E}$ were both inhibitory to $R$. mucilaginosa and $B$. megaterium. Compounds $\mathrm{F}$ and $\mathrm{G}$ were both phytotoxic and inhibited $B$. megaterium. Thus, the culture filtrate of $P$. cichorii SF1-54 is a complex mixture of several bioactive metabolites.

\section{Chemical characterization of compounds $D$ and $E$ (cichofactins).}

The concentration of compounds $\mathrm{D}$ and $\mathrm{E}$ in the culture filtrate obtained from $\mathrm{SRM}_{\mathrm{AF}}$ medium was $29 \pm 15 \mathrm{mg} / \mathrm{liter}$ based on calculated data from five different cultures. Several media other than $\mathrm{SRM}_{\mathrm{AF}}$ and various incubation periods and temperatures were tested for production of all the bioactive compounds by $P$. cichorii SF1-54 but only compounds D and $\mathrm{E}$ were consistently produced in high amounts (data not shown), indicating that these metabolites could be the main compounds produced by $P$. cichorii SF1-54. In addition to consistent production, compounds D and E exhibited not only surfactant but also inhibitory activities to $R$. mucilaginosa and $B$. megaterium. Thus, we first focused on identification and characterization of these two metabolites.

HPLC-purified samples of compounds D and E were submitted to acid hydrolysis, and further analysis of the released amino acids revealed that both molecules contained Leu, Val, and Glx (representing either Gln or Glu) residues in similar molar ratios of 1.91:1.05:5.12 and 2.02:1.03:5.01, respectively. These results support the peptidic nature of compounds D and $\mathrm{E}$ and they were further characterized by HPLC-ESI-MS using parameters to optimize in-source fragmentation. Identification of $\mathrm{b}$ and $\mathrm{y}^{\prime \prime}$ ions revealed very similar fragmentation patterns
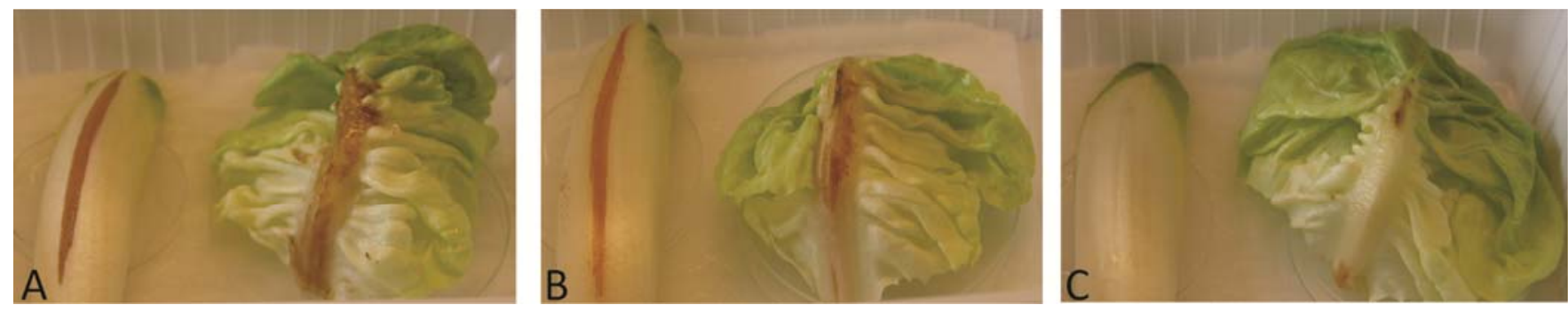

Fig. 1. Necrosis induction in chicory and lettuce leaves at $24 \mathrm{~h}$ after inoculation with A, Pseudomonas cichorii SF1-54 $\left(1 \times 10^{8} \mathrm{CFU} / \mathrm{ml}\right)$; B, crude culture filtrate of P. cichorii SF1-54; and C, noninoculated $\mathrm{SRM}_{\mathrm{AF}}$ medium (the noninoculated control treatment). Each treatment was repeated three times, and a picture representative of each of the treatments is shown. 
of the $[\mathrm{M}+\mathrm{H}]^{+}$ions $(\mathrm{m} / \mathrm{z}, 1,109$ and 1,137 , respectively) corresponding to compounds D and E (Table 1; Supplementary Fig. $\mathrm{S} 1$ ). However, $\mathrm{m} / \mathrm{z}$ values of b-ion fragments were $28 \mathrm{Da}$ larger for compound $\mathrm{E}$ (Table 1), suggesting that its fatty acid chain contains two extra methylene groups. The presence of a 3-hydroxydecanoyl fatty acid in compound D and a 3-hydroxydodecanoyl fatty acid in compound $\mathrm{E}$ is fully supported by the detection of ions at $m / z 284$ and 312, respectively, in accordance to the [FA-Leu]-fragments.

Based on the fragmentation pattern, both lipopeptides could have the peptide sequence Leu-Leu-Gln-Leu-Gln-Val-LeuLeu.

\section{HR-ESI-MS-MS analyses.}

In-depth structural characterization was obtained using HRESI-MS-MS performed on the $[\mathrm{M}+\mathrm{Na}]^{+}$form of compounds D and $\mathrm{E}$. The exact $\mathrm{m} / z$ of $[\mathrm{M}+\mathrm{Na}]^{+}$of compound $\mathrm{D}$ is $1,131.732$ and of compound $\mathrm{E}$ is 1,159.762 (calculated masses are $1,131.737$ and $1,159.768$ for $\mathrm{C}_{55} \mathrm{H}_{100} \mathrm{~N}_{10} \mathrm{O}_{13} \mathrm{Na}$ and $\mathrm{C}_{57} \mathrm{H}_{104} \mathrm{~N}_{10} \mathrm{O}_{13} \mathrm{Na}$, respectively). These masses suggest that the compounds are linear because their mass would be $18 \mathrm{Da}$ smaller (loss of one water molecule for cyclization) if they were cyclic. Moreover, the first loss of Leu-COOH $(\mathrm{m} / \mathrm{z}, 1,018$ and 1,046, respectively) is an additional evidence for a linear structure.
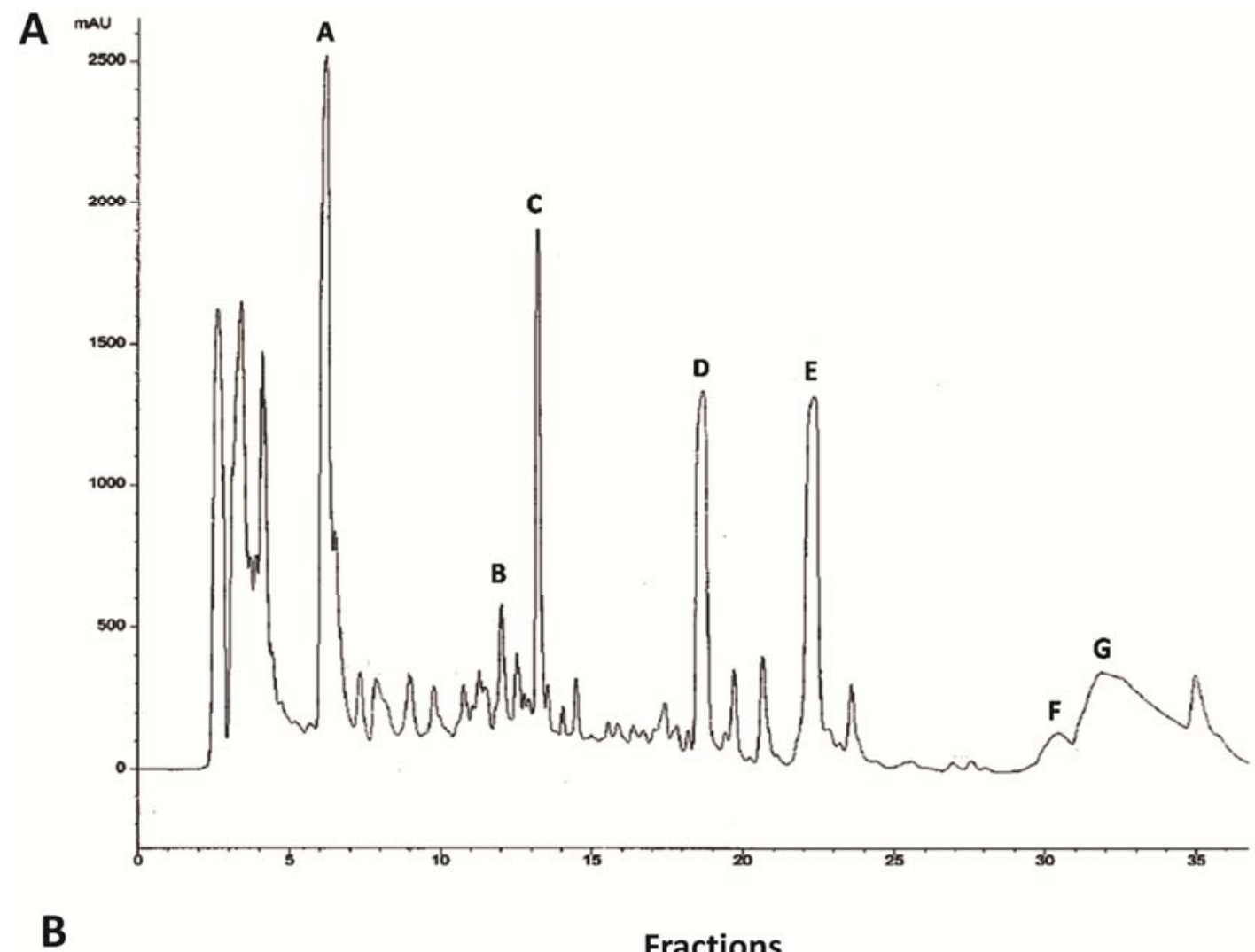

B

\section{Fractions}

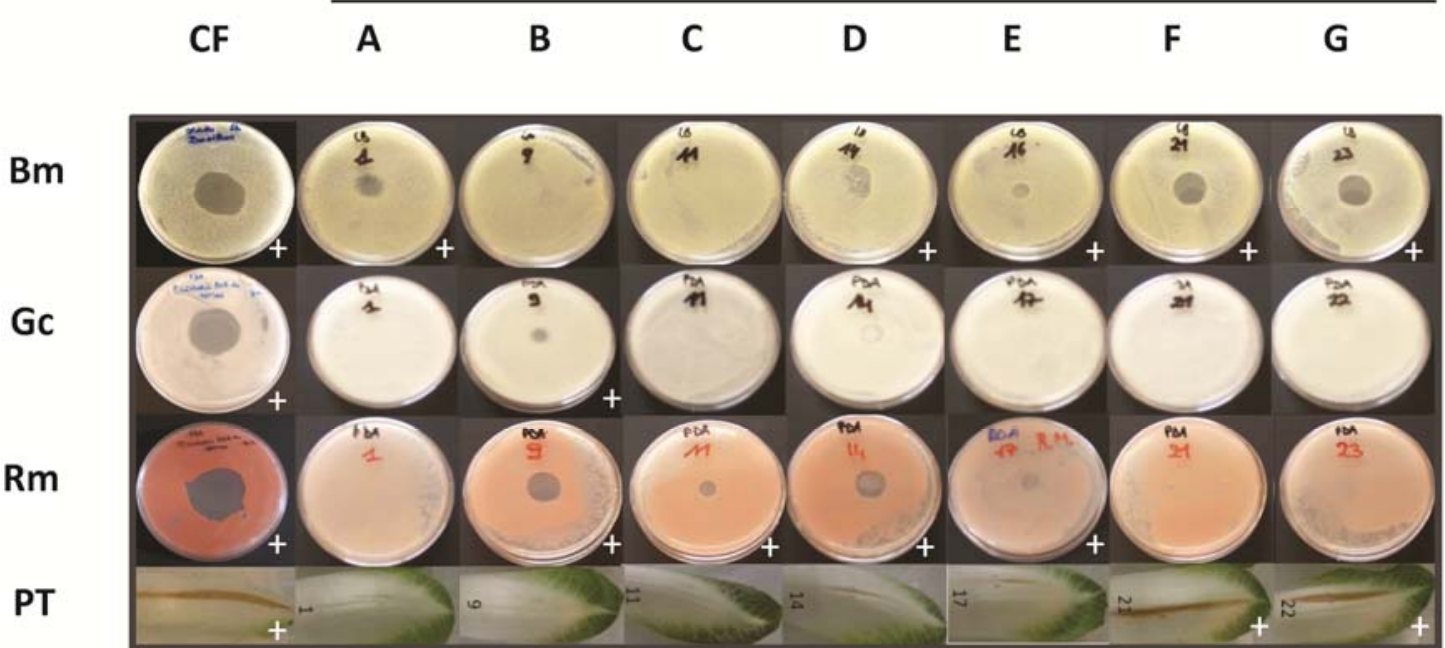

Fig. 2. A, Reverse-phase high-performance liquid chromatography (RP-HPLC) chromatogram of the semipurified extract of Pseudomonas cichorii SF1-54. Each peak was checked for surfactant activity, antimicrobial activity, and phytotoxic activity in chicory leaves. All (bio)active peaks are indicated with a letter. B, Antimicrobial and phytotoxic activity of each bioactive fraction separated by RP-HPLC. Antimicrobial activity against Bacillus megaterium (Bm), Geotrichum candidum $(\mathrm{Gc})$, and Rhodotorula mucilaginosa $(\mathrm{Rm})$ and phytotoxicity to chicory (PT) of each fraction was assayed. CF: culture filtrate of P. cichorii SF1-54. 
All pertinent fragments from the HR-ESI-MS-MS spectra of the $[\mathrm{M}+\mathrm{Na}]^{+}$form of compounds $\mathrm{D}$ and $\mathrm{E}$ are shown in Table 2. The b-type ions are formed upon collision activation (CA) of the $[\mathrm{M}+\mathrm{Na}]^{+}$species by rearrangement processes (Fuchs and Budzikiewicz 2001) (Supplementary Fig. S2). The degradation of the peptide chain by elimination of the C-

Table 1. Listing of $b$ and $y^{\prime \prime}$ ions obtained from the $[M+H]^{+}$species of compounds $\mathrm{D}$ and $\mathrm{E}$ formed in the liquid chromatography electrospray ionization mass spectrometry analysis ${ }^{\mathrm{a}}$

\begin{tabular}{lcccccc}
\hline & \multicolumn{2}{c}{ b ions } & & \multicolumn{2}{c}{$\mathbf{y}^{\prime \prime}$ ions } \\
\cline { 2 - 3 } \cline { 5 - 6 } Peptide & Compound D & Compound E & & Compound D & Compound E \\
\hline FA & $(171)$ & $(199)$ & & $\ldots$ & $\ldots$ \\
Leu & 284 & 312 & & $(939)$ & $(939)$ \\
Leu & 397 & 425 & & $(826)$ & $(826)$ \\
Gln & 525 & 553 & & 713 & 713 \\
Leu & 638 & 666 & & 585 & 585 \\
Gln & 766 & 794 & & 472 & 472 \\
Val & 865 & 893 & & 344 & 344 \\
Leu & 978 & 1,006 & & 245 & 245 \\
Leu & 1,091 & 1,119 & & $(132)$ & $(132)$ \\
{$[\mathrm{M}+\mathrm{H}]^{+}$} & 1,109 & 1,137 & & $\ldots$ & $\ldots$ \\
\hline
\end{tabular}

${ }^{a}$ Numbers in parentheses are calculated values not observed in the mass spectra. terminal amino acid with back transfer of the hydroxyl group can be repeated several times (sequential loss of $\mathrm{NH}=\mathrm{CHR}$ units). Thus, the HR-ESI-MS-MS fragmentation pattern supported the LC-ESI-MS data completely: a 3-hydroxydecanoyl fatty acid in compound D and a 3-hydroxydodecanoyl fatty acid in compound E coupled to a peptide moiety containing Leu-Leu-Gln-Leu-Gln-Val-Leu-Leu for both compounds.

Comparison of compounds D and E with previously described lipopeptides produced by Pseudomonas spp. revealed that these molecules are new members of the syringafactin family. The only difference is the replacement of Thr present at position five in syringafactins A and D by Gln in the compounds produced by $P$. cichorii SF1-54. Because of the high structural resemblance of these compounds to the syringafactins $\mathrm{A}$ and $\mathrm{D}$, we renamed compounds $\mathrm{D}$ and $\mathrm{E}$ cichofactins $\mathrm{A}$ and $\mathrm{B}$, respectively.

Identification and bioinformatic analysis of putative cichofactin synthetase-encoding genes.

Because cichofactins show high structural similarities with the syringafactins of $P$. syringae pv. tomato DC3000, the genome of $P$. cichorii SF1-54 (unpublished) was compared with the genome sequence of $P$. syringae pv. tomato DC3000 using

Table 2. Listing of fragment ions and of $\mathrm{y}^{\prime \prime}$ ions obtained from the $[\mathrm{M}+\mathrm{Na}]^{+}$species of compounds $\mathrm{D}$ and $\mathrm{E}$ formed in the high-resolution electrospray ionization tandem mass spectrometry analysis ${ }^{\mathrm{a}}$

\begin{tabular}{|c|c|c|c|c|c|c|}
\hline \multirow{3}{*}{$\frac{\text { Peptide }}{\text { FA }}$} & \multicolumn{4}{|c|}{ Fragment ions } & \multicolumn{2}{|c|}{$y^{\prime \prime}$ ions } \\
\hline & \multicolumn{2}{|c|}{ Compound D } & \multicolumn{2}{|c|}{ Compound E } & \multirow{2}{*}{ Compound D } & \multirow{2}{*}{ Compound E } \\
\hline & (211) & $(165)$ & (239) & (193) & & \\
\hline Leu & 324 & (278) & (352) & (306) & (961) & (961) \\
\hline Leu & 437 & 391 & 465 & 419 & 848 & 848 \\
\hline Gln & 565 & 519 & 593 & 547 & 735 & 735 \\
\hline Leu & 678 & 632 & 706 & 660 & 607 & 607 \\
\hline Gln & 806 & 760 & 834 & 788 & 494 & 494 \\
\hline Val & 905 & 859 & 933 & 887 & (366) & (366) \\
\hline Leu & 1,018 & 972 & 1,046 & 1,000 & (267) & (267) \\
\hline Leu $\left([\mathrm{M}+\mathrm{H}]^{+}\right)$ & 1,131 & $\ldots$ & 1,159 & $\ldots$ & (154) & (154) \\
\hline
\end{tabular}

${ }^{\text {a }}$ Numbers in parentheses are calculated values not observed in the mass spectra.

$$
-=1 \mathrm{~kb}
$$

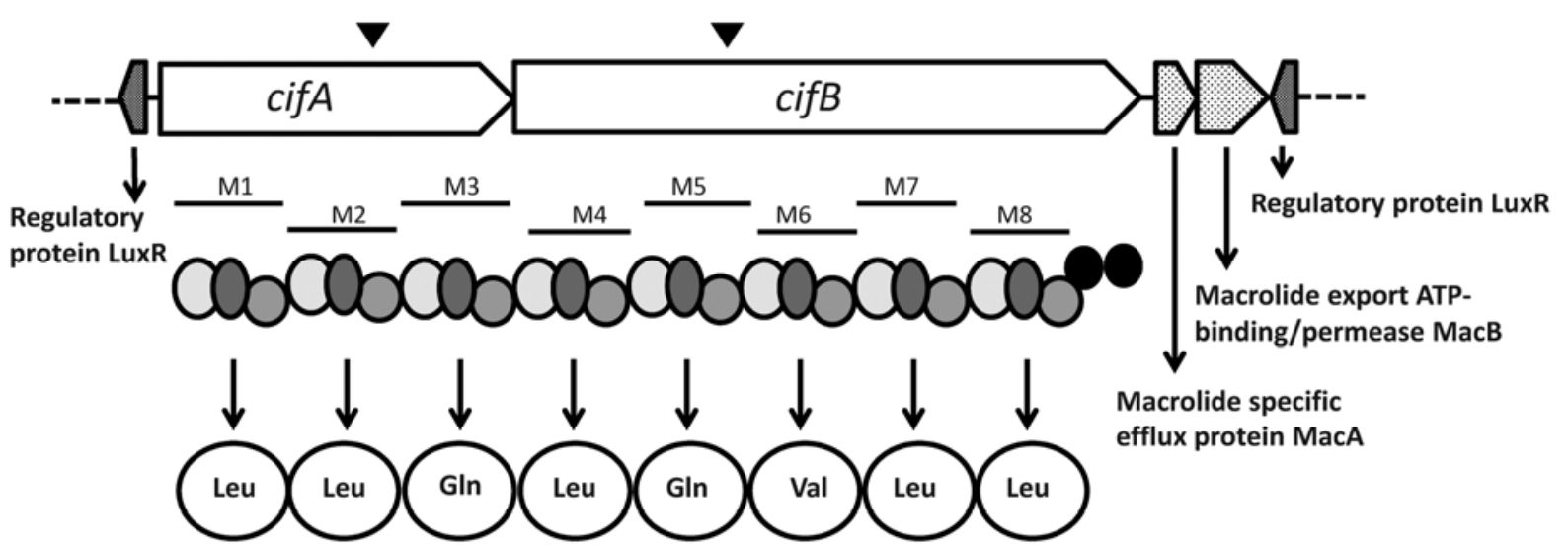

Fig. 3. Schematic representation of the cichofactin biosynthetic gene clusters and the flanking open reading frames in the Pseudomonas cichorii SF1-54 genome. Module and domain organization are indicated below cifA and cifB genes. Predicted amino acid specificity is represented below each module and all amino acids are identified by standard three-letter biochemical notation. The region between arrowheads was deleted in the cichofactin-deficient mutant. 
the MAUVE multiple genome alignment system to identify the gene cluster which encodes the NRPS for cichofactins synthesis.

In the genome of $P$. cichorii SF1-54, a gene cluster was identified containing two large genes, cifA and cifB, that are 9,498 and $17,734 \mathrm{bp}$ in size and encode for three and five NRPS modules, respectively, with specific condensation (C), adenylation (A), and thiolation (T) domains (Fig. 3). Both genes exhibit two typical features of NRPS genes involved in lipopeptide synthesis: the presence of an N-terminal C domain in the initiating module and two tandem thioesterase domains at the end of the NRPS cluster. Furthermore, cifA and cifB genes of $P$. cichorii SF1-54 showed 76 and $75 \%$ identity at the amino acid level to syringafactin-encoding genes $s y f A$ and $s y f B$, respectively, of $P$. syringae pv. tomato DC3000.

To predict the peptide sequence of cichofactins from genome sequencing data, bioinformatic analysis of the A domain from each NRPS module was performed. The putative peptide sequence of cichofactins is Leu-Leu-Gln/Asp-Leu-Gln/AspVal-Leu-Leu (Supplementary Table S1). The prediction with NRPSpredictor2 for the amino acids at third and fifth position is based on the specificity codes which, in both cases, show $70 \%$ identity with the specificity code of Gln and Asp. According to the results of structural analysis of cichofactins, both the third and fifth amino acids are Gln and the prediction is in full agreement with the peptide sequence of cichofactins determined by MS.

Furthermore, the D/L configuration of amino acid residues of cichofactins was investigated by phylogenetic analysis of the peptide sequences of $\mathrm{C}$ domains. In Pseudomonas spp., dual condensation/epimerization $(\mathrm{C} / \mathrm{E})$ domains are responsible for generating D-residues into lipopeptides (Balibar et al. 2005; Rausch et al. 2007). According to the phylogenetic analysis, $C$ domains of modules $2,3,4,6$, and 8 could be dual C/E domains; therefore, the peptidic structure of cichofactins could be D-Leu-D-Leu-D-Gln-L-Leu-D-Gln-L-Val-D-Leu-L-Leu. The locations of dual $\mathrm{C} / \mathrm{E}$ domains of cichofactins are identical to those of syringafactins (Berti et al. 2007).
LuxR-type regulators and transporter genes are often positioned up- and downstream of the lipopeptide biosynthesis genes in various pseudomonads (Berti et al. 2007; de Bruijn and Raaijmakers 2009; de Bruijn et al. 2008; Dubern et al. 2008; Kang and Gross 2005; Quigley et al. 1993; Roongsawang et al. 2003; Vallet-Gely et al. 2010). Therefore, we examined the flanking regions of the cichofactin biosynthesis cluster in the $P$. cichorii SF1-54 genome. Two open reading frames (ORF) downstream of the cichofactin biosynthesis cluster showed sequence similarities to subunits of a multidrug efflux pump, MacA (77\% protein identity with P. entomophila L48) and MacB $(89 \%$ protein identity with $P$. syringae pv. tomato DC3000) (Fig. 3). On each side of the cichofactin biosynthesis cluster, two ORF were identified showing sequence similarity with the LuxR family of transcriptional regulators (66 and $69 \%$ protein identity with $P$. syringae pv. tabaci ATCC 11528 and $P$. syringae pv. maculicola ES4326, respectively).

\section{Biological role of cichofactins produced by $P$. cichorii SF1-54.}

To investigate the biological role of the cichofactins and their importance in pathogenicity for $P$. cichorii SF1-54, we constructed a cichofactin-deficient mutant, SF1-54- $\Delta$ cifAB, by deleting a 9,715-bp fragment within the cichofactin-encoding genes cifA and cifB (Fig. 3). LC-ESI-MS analysis confirmed that this mutant was completely abolished in production of both cichofactins (Fig. 4). In addition, the production of the phytotoxic compounds $\mathrm{F}$ and $\mathrm{G}$ was approximately 10 times higher in the mutant compared with the wild type. Deletion of the cichofactin biosynthesis genes did not influence the production of compound $\mathrm{A}$, while the amounts of compounds $\mathrm{B}$ and $\mathrm{C}$ were too low to be detected in the semipurified culture filtrate of the wild type and the cichofactin mutant by LC-ESIMS analysis.

When $P$. cichorii SF1-54 cells were suspended into a droplet of water on parafilm, the water droplet collapsed immediately, but a cell suspension of $P$. cichorii SF1-54- $\Delta$ cifAB did not

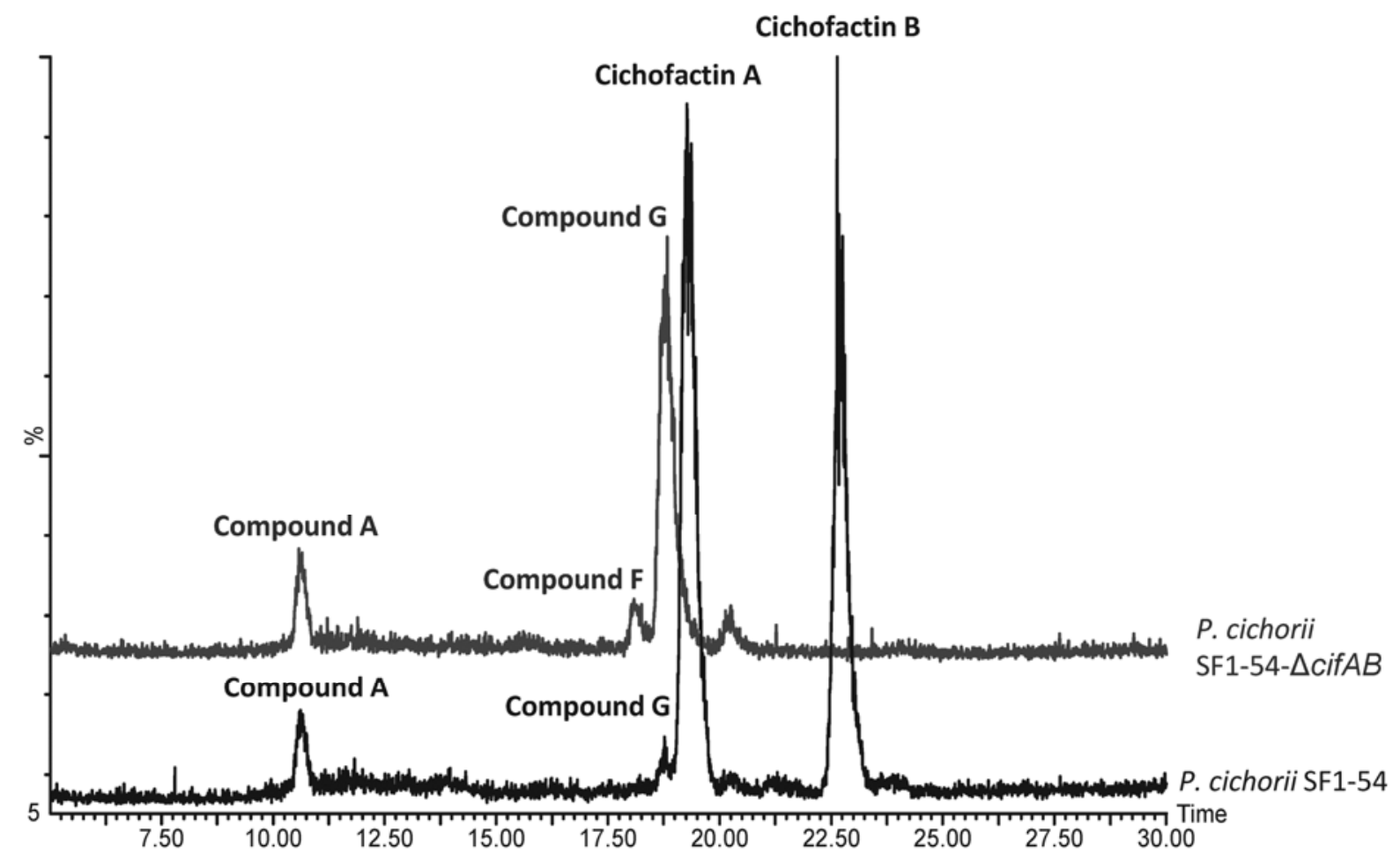

Fig. 4. Liquid chromatography electrospray ionization mass spectrometry analysis of culture supernatants of Pseudomonas cichorii SF1-54 and its cichofactindeficient mutant.

Vol. 26, No. 5, 2013 / 589 
cause spreading of the water on the parafilm surface (data not shown). Because of the biological activity of the remaining compounds, the cichofactin-deficient mutant retained the ability to inhibit growth of $B$. megaterium, $G$. candidum, and $R$. mucilaginosa in direct antagonistic assays. However, $P$. cichorii SF1-54- $\triangle$ cifAB produced remarkably larger inhibition zones than the wild type against $B$. megaterium, probably due to the overproduction of compounds F and G. The mean inhibition zone of $P$. cichorii SF1-54- $\Delta$ cifAB was $47 \mathrm{~mm}$ compared with $35 \mathrm{~mm}$ for $P$. cichorii SF1-54.

The cichofactin-deficient mutant still induced discoloration and necrosis of chicory leaves, which is not surprising because the mutant overproduces the phytotoxic compounds $\mathrm{F}$ and $\mathrm{G}$ (Fig. 4).

Syringafactins produced by $P$. syringae pv. tomato DC3000 and $P$. syringae pv. syringae $\mathrm{B} 748$ a function as biosurfactants
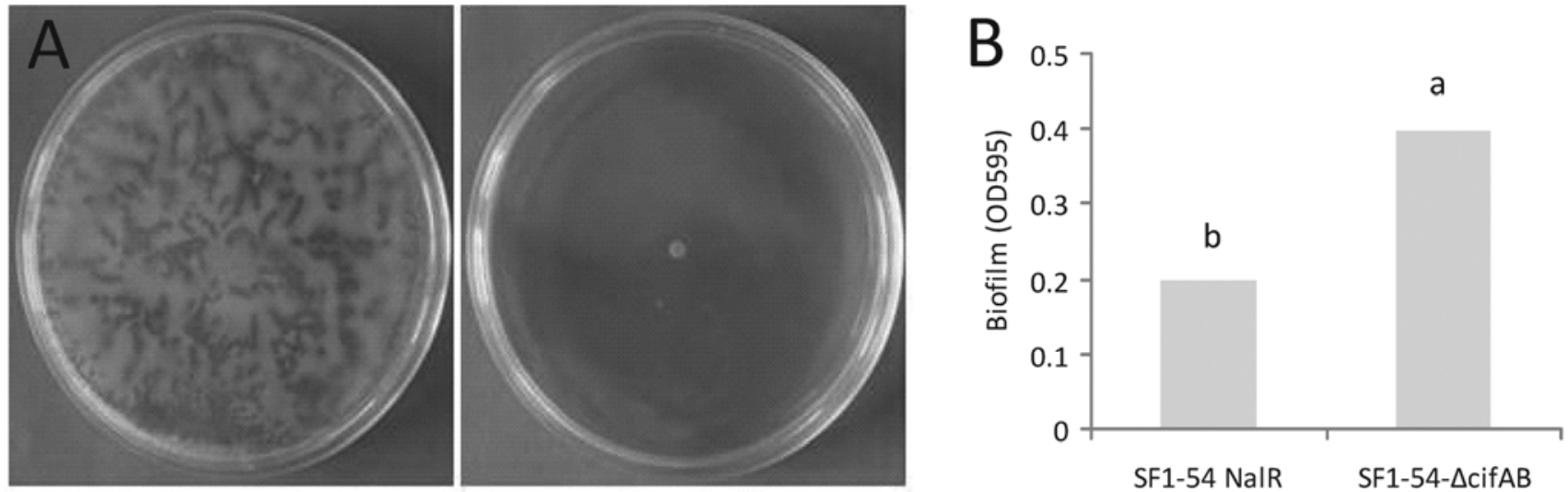

C
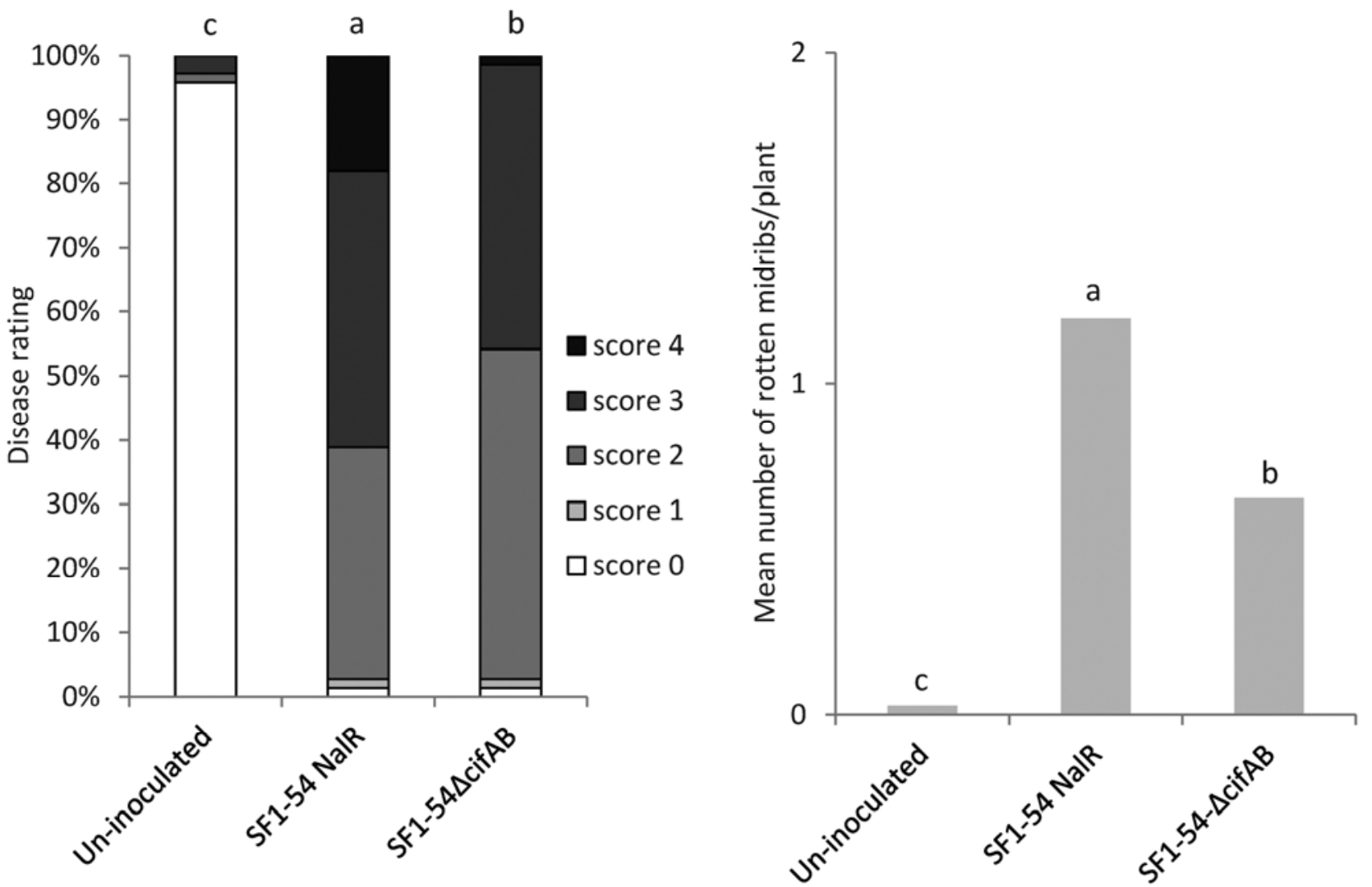

Fig. 5. Biological roles of cichofactins in Pseudomonas cichorii SF1-54. A, Swarming behavior of P. cichorii SF1-54 and its cichofactin-deficient mutant on Luria-Bertani soft agar $(0.5 \%$ [wt/vol]) plates. P. cichorii SF1-54 covered the entire plate within $48 \mathrm{~h}$ after inoculation (left panel), whereas its cichofactin-deficient mutant was impaired in motility (right panel). B, Biofilm formation of $P$. cichorii SF1-54Nal ${ }^{\mathrm{R}}$ and its cichofactin-deficient mutant. Spectrophotometric quantification of the biofilm formed by $P$. cichorii SF1-54Nal ${ }^{\mathrm{R}}$ and its cichofactin-deficient mutant $(P$. cichorii SF1-54- $\Delta$ cifAB) $24 \mathrm{~h}$ after inoculation; the quantity of crystal-violet-stained biofilm was determined by measuring optical density at $595 \mathrm{~nm}$. The experiment (seven repetitions per treatment) was carried out three times and similar results were obtained each time. Representative data from one experiment are presented. Bars indicated with the same letter are not statistically different based on nonparametric Kruskal-Wallis and Mann-Whitney comparisons $(P<0.05)$. C, Virulence of $P$. cichorii SF1-54Nal ${ }^{\mathrm{R}}$ and its cichofactin-deficient mutant (SF1-54- $\Delta$ cifAB) on greenhouse-grown butterhead lettuce. Plants were inoculated with suspensions of $P$. cichorii strains $\left(1 \times 10^{6} \mathrm{CFU} / \mathrm{ml}\right)$ after head formation of lettuce. Virulence is represented as disease severity (left panel) and mean number of diseased midribs (right panel). Tap water was used as the noninoculated control. The experiment was carried out twice with similar results. Data from one experiment are shown. Bars indicated with the same letter are not statistically different based on nonparametric Kruskal-Wallis and Mann-Whitney comparisons $(P<0.05)$. 
and are involved in swarming motility (Berti et al. 2007; Burch et al. 2010). P. cichorii SF1-54 swarmed outward from the inoculation point to cover the entire plate containing soft LuriaBertani (LB) medium (0.5\% agar) within $48 \mathrm{~h}$, whereas swarming motility was completely abolished in the cichofactin-deficient mutant (Fig. 5A).

Because lipopeptides produced by plant-associated Pseudomonas spp. are often described to influence biofilm formation (de Bruijn et al. 2007, 2008; Kuiper et al. 2004; Roongsawang et al. 2003), we tested the influence of cichofactins on biofilm production of $P$. cichorii SF1-54. P. cichorii SF1-54 formed biofilms in polystyrene 96 -well microtiter plates, and the biofilm formation of the cichofactin-deficient mutant was significantly improved compared with the wild type (Fig. 5B).

To determine the effect of cichofactins on the virulence of $P$. cichorii SF1-54, the wild type or its cichofactin-deficient mutant were spray-inoculated on butterhead lettuce in greenhouse experiments. Lettuce plants inoculated with the cichofactindeficient mutant exhibited significantly less rotten midribs than lettuce plants inoculated with the wild type, which is also reflected in the significantly lower disease severity score obtained with the mutant $(P<0.05)$ (Fig. 5C). However, when the wild type or the cifAB-deletion mutant were injected in lettuce midribs, both strains grew vigorously and reached similar population densities in the inoculated section at 1, 2, and 3 days postinoculation (Supplementary Fig. S3). Furthermore, the effect of cichofactins on spread of $P$. cichorii in lettuce midribs was investigated (Supplementary Table S2). Both the wild-type strain and the cichofactin-deficient mutant moved to the adjacent midrib section (Supplementary Fig. S4) 3 days postinoculation but the mutant moved at a significantly slower rate than the wild type.

A successful attachment is the first step in colonization and pathogenesis (Danhorn and Fuqua 2007; Turnbull et al. 2001).
Hence, we wanted to understand whether cichofactins are involved in attachment of $P$. cichorii on three different regions of leaf surface. The wild-type strain and the cichofactin-deficient mutant attached equally well on the leaf surface but, for the petiole and center regions, very small but significant differences in bacterial attachment were observed.

Lettuce tissue inoculated with $P$. cichorii SF1-54 was analyzed using LC-ESI-MS to determine lipopeptide production of $P$. cichorii SF1-54 in planta. Cichofactins were not detected the first day after strain injection but the concentration of cichofactins gradually increased over the next 3 days to reach amounts of 1.2 to $8.1 \mu \mathrm{g} / \mathrm{g}$ of leaf fresh weight in two different assays. No peaks corresponding to possible lipopeptide compounds were observed in uninfected lettuce tissue. In addition, no trace of the other lipopeptides could be detected (Fig. 6).

\section{$P$. cichorii strains and isolates differ in swarming motility and cichofactin production.}

Belgian $P$. cichorii isolates from lettuce can be categorized into three subgroups based on colony morphology and BOXpolymerase chain reaction (PCR) patterns (Cottyn et al. 2009). Isolates belonging to the $\mathrm{C} 3$ group are significantly less virulent on lettuce than isolates of the $\mathrm{C} 1$ and $\mathrm{C} 2$ groups (Pauwelyn et al. 2011). The swarming ability of two P. cichorii isolates of each subgroup next to SF1-54 (C1 group) - the Japanese tar spot strain SPC9018 (C2 group), the Californian varnish spot strain 9D42 (related to the C3 group), the chrysanthemum strain NCPPB 907 (not related with any of the three groups), and the type strain NCPPB $943^{\mathrm{T}}$ (not related with any of the three groups)-was investigated. $P$. cichorii isolates belonging to different groups differ in their swarming motility, with isolates from groups $\mathrm{C} 1$ and $\mathrm{C} 2$ swarming more rapidly than isolates of the C3 group (Fig. 7A). Surprisingly, the varnish spot

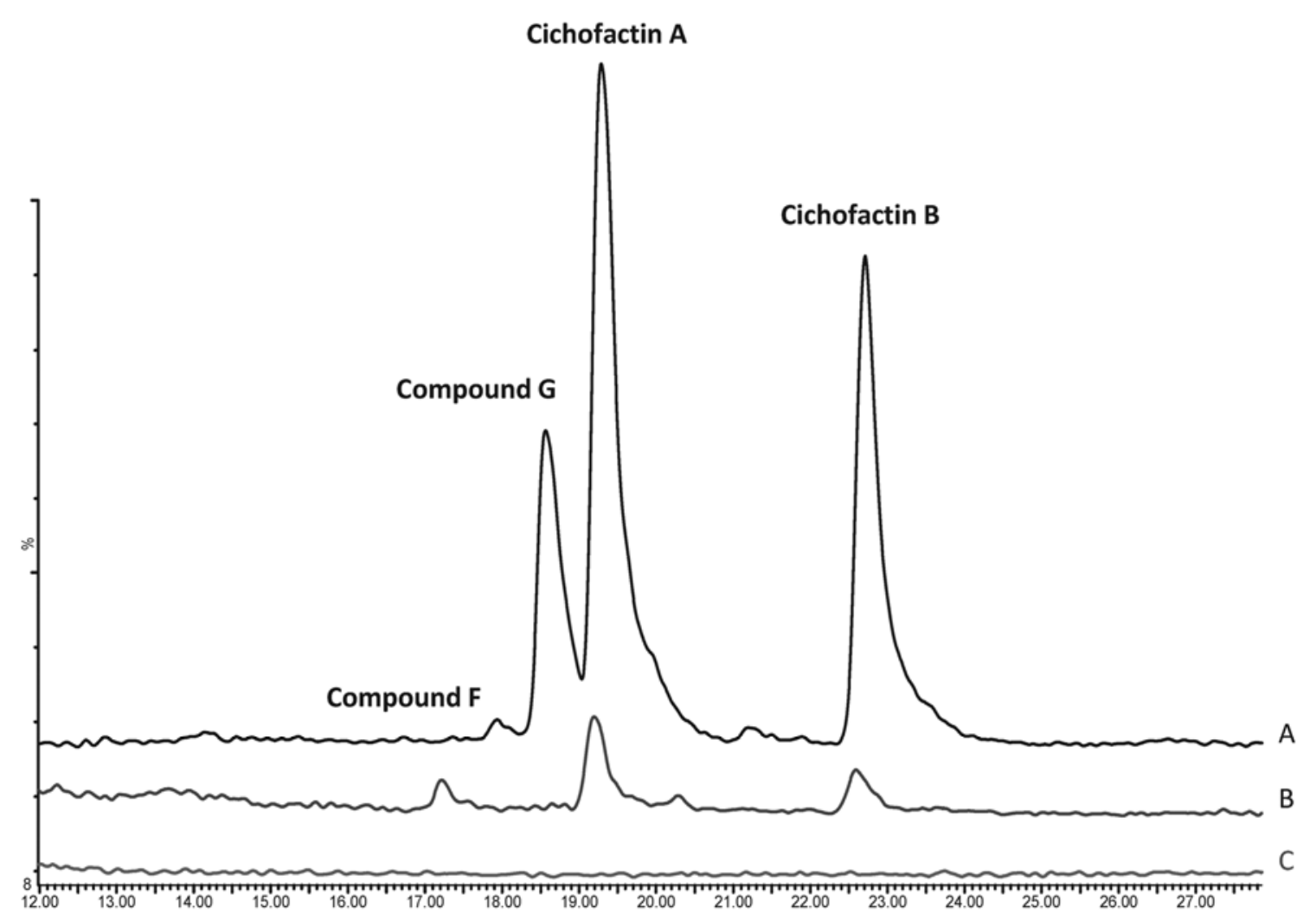

Fig. 6. Liquid chromatography electrospray ionization mass spectrometry detection of Pseudomonas cichorii SF1-54 lipopeptides in A, semipurified culture filtrate of P. cichorii SF1-54; B, extract of lettuce tissue infected with P. cichorii SF1-54; and C, extract of noninoculated lettuce tissue. Lipopeptides were extracted and analyzed 5 days postinoculation. 

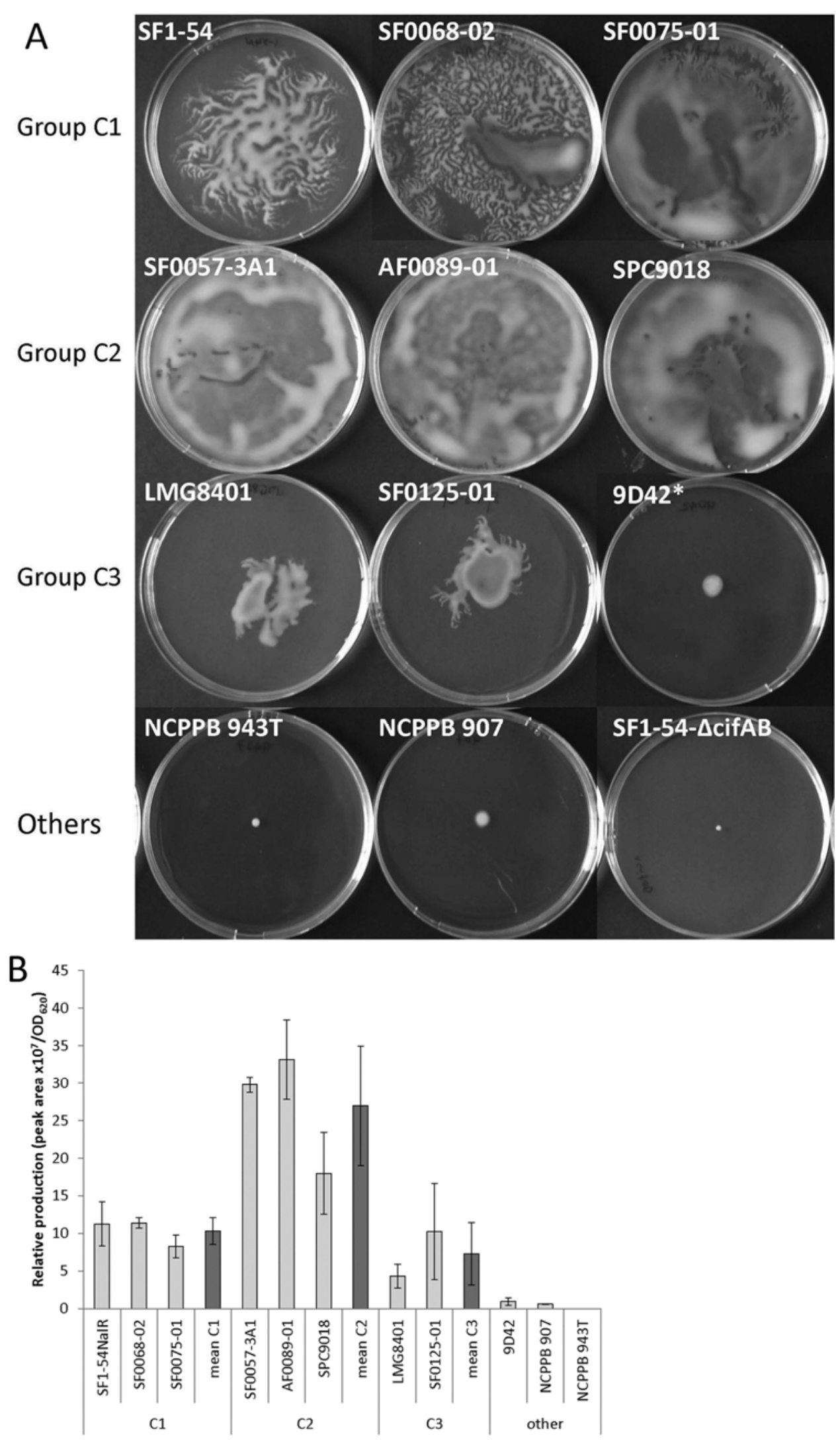

Fig. 7. A, Swarming behavior of Pseudomonas cichorii isolates of different groups as defined by Cottyn and associates (2009) on Luria-Bertani (LB) soft agar $(0.5 \%$ [wt/vol] $)$ plates. Plates were photographed $24 \mathrm{~h}$ after incubation. *Strain 9D42 is related to group C3. B, Quantification of cichofactin production by P. cichorii isolates of different groups on LB soft agar $(0.5 \%$ [wt/vol]) plates. After $24 \mathrm{~h}$ of incubation, the bacterial cells were scraped from the swarming plates and suspended in $100 \%$ acetonitrile, and the optical density at $620 \mathrm{~nm}\left(\mathrm{OD}_{620}\right)$ of each sample was measured as the indicator of biomass. Cichofactin production of each sample was measured by high-performance liquid chromatography electrospray ionization mass spectrometry by using single-ion recording integration of peaks corresponding to the exact mass of A and B homologues. Data are expressed as relative production based on the peak area per $\mathrm{OD}_{620}$. Vertical bars indicate standard deviations. For each isolate, two plates were analyzed. No production of cichofactins was detected in the type strain of P. cichorii NCPPB $943^{\mathrm{T}}$. 
strain 9D42, the type strain NCPPB $943^{\mathrm{T}}$ and chrysanthemum strain NCPPB 907 did not show swarming motility. Interestingly, these three strains are weakly virulent or nonvirulent on lettuce (Pauwelyn et al. 2011) (Supplementary Table S3).

In addition, the level of cichofactin production in the various $P$. cichorii isolates was measured by HPLC-ESI-MS (Fig. 7B). Isolates of the $\mathrm{C} 2$ group secreted much more cichofactin than isolates of the $\mathrm{C} 1$ and $\mathrm{C} 3$ group. Very low amounts of cichofactins were produced by strains 9D42 and NCPPB 907, while no cichofactins could be detected in the type strain NCPPB $943^{\mathrm{T}}$. However, the presence of the cif genes could be detected in all strains with the primers (Table 3 ) used to construct the deletion plasmid pMQ30- $\triangle$ cifAB (data not shown). Our results show a correlation between cichofactin production and swarming and suggest, indirectly, an impact on virulence in lettuce.

\section{DISCUSSION}

Several plant-pathogenic Pseudomonas spp., such as $P$. syringae pv. syringae, $P$. fuscovaginae, $P$. corrugata, and $P$. fluorescens 5064, are known to produce (cyclic) lipopeptides (Bender et al. 1999; Catara 2007; Flamand et al. 1996; Hildebrand et al. 1998). Because these lipopeptides are surfactants, often exhibiting antimicrobial or phytotoxic activity, bioactivity assays are commonly used to assess their presence (Bender et al. 1999; Raaijmakers et al. 2010).

In this study, by means of bioassays, we showed that $P$. cichorii SF1-54 has surfactant, antimicrobial, and phytotoxic activity. These results confirm and extend the findings of $\mathrm{Hu}$ and associates (1998), who showed the production of an antibiotic compound by $P$. cichorii, and of Lazzaroni and associates (2003), mentioning the production of both phytotoxic and antibiotic compounds by $P$. cichorii. However, these compounds were not further characterized. Because the culture filtrate of $P$. cichorii SF1-54 showed characteristics similar to those of $P$. cichorii SF1-54 cells, bioactivity was due to compounds released by bacteria in the culture filtrate. Because tar symptoms caused by $P$. cichorii on crisphead lettuce in Japan are partly due to apoptosis-like programmed cell death (Kiba et al. 2006, 2009), we suggest that phytotoxic compounds or virulence factors in the culture filtrate may be involved in the induction of apoptosis in lettuce.

An HPLC chromatogram of the semipurified extract from the culture filtrate of $P$. cichorii SF1-54 revealed that $P$. cichorii SF1-54 produces a complex mixture of several metabolites (Fig. 2). The HPLC elution pattern of the semipurified extract was similar to the elution pattern of the lipopeptide metabolites of $P$. syringae pv. syringae (Ballio et al. 1991) and P. fuscovaginae (Flamand et al. 1996), which is characterized by the presence of two groups of compounds with different polarity; more specifically, the lipodepsinonapeptides (such as syringomycins) and the more hydrophobic lipopeptides, such as syringopeptins and fuscopeptins. Preliminary data suggest that compounds B and C are pseudomycin like (Ballio et al. 1994), whereas compounds $\mathrm{F}$ and $\mathrm{G}$ are structurally related to corpeptin, a phytotoxic lipopeptide produced by $P$. corrugata (Emanuele et al. 1998), but this has to be confirmed by further chemical analysis.

HPLC fractionation of the culture filtrate of $P$. cichorii SF154 showed that the bioactivity of the strain could be ascribed to seven different compounds (Fig. 2). These compounds all showed surfactant activity, which is the primary characteristic of lipopeptide metabolites. However, bioactivities of these compounds are clearly different. These tests showed that two of them (D and E) were particularly interesting and their chemical structure was further investigated. Because of the close resemblance of these compounds to syringafactins (Berti et al. 2007), they were renamed cichofactins A and B. Their molecular masses are 1,109 and 1,137 Da, respectively. Their similar bioactivity and their molecular weight difference of $28 \mathrm{Da}$ that corresponds to two methylene groups show that these compounds are homologs, only differing in the length of their fatty acid moieties. This relationship has been found with several other Pseudomonas lipopeptide homologs such as several syringopeptins (Ballio et al. 1991; Grgurina et al. 2002, 2005; Isogai et al. 1995). Up till now, cichofactins and syringafactins

Table 3. Strains, plasmids, and primers used in this study

\begin{tabular}{|c|c|c|}
\hline Strain, plasmid, or primer & Genotype or description $^{a}$ & Source or reference \\
\hline \multicolumn{3}{|l|}{ Strains } \\
\hline \multicolumn{3}{|l|}{ Pseudomonas cichorii } \\
\hline SF1-54, SF0068-02, SF0075-01, SF0057- & & \\
\hline 3A1, AF0089-01, LMG8401, SF0125-01 & Natural isolates from infected greenhouse butterhead lettuce in Belgium & Cottyn et al. 2011 \\
\hline 9D42 & Isolate from lettuce with varnish spot disease in California & Grogan et al. 1977 \\
\hline SPC9018 & Isolate from lettuce with tar disease in Japan & Kiba et al. 2006 \\
\hline NCPPB $943^{\mathrm{T}}$ & Type strain isolated from Cichorium endivia in Germany $\left(=\mathrm{LMG} 2162^{\mathrm{T}}\right)$ & Cottyn et al. 2009 \\
\hline NCPPB 907 & Isolate from Chrysanthmum manifolium in USA & Yamamoto et al. 2000 \\
\hline SF1-54NalR & Spontaneous nalidixic acid-resistant mutant of SF1-54 & This study \\
\hline SF1-54- $\Delta$ cifAB & Cichofactin deficient-mutant of SF1-54 NalR & This study \\
\hline Escherichia coli $\mathrm{S} 17-1$ & 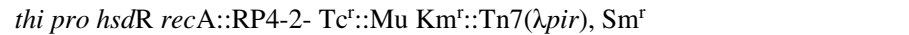 & Simon et al. 1983 \\
\hline Bacillus megaterium LMG 7127 & An indicator strain for lipopeptide & $\ldots$ \\
\hline Rhodolotula mucilaginosa MUCL 30397 & An indicator strain for lipopeptide & $\ldots$ \\
\hline Geotrichum candidum MUCL 28959 & An indicator strain for lipopeptide & \\
\hline Saccharomyces cerevisiae InvSc1 & 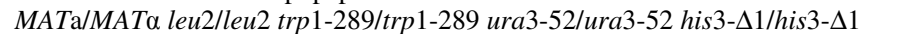 & Invitrogen \\
\hline \multicolumn{3}{|l|}{ Plasmids } \\
\hline pMQ30 & $\begin{array}{l}\text { 7.6 kb mobilizable suicide vector used for gene replacements in Pseudomonas } \\
\text { spp.; SacB, URA3, } \mathrm{Gm}^{\mathrm{r}}\end{array}$ & Shanks et al. 2006 \\
\hline pMQ30-cifAB & $\begin{array}{l}\text { pMQ30 containing two ca. } 1 \mathrm{~kb} \text { fragments of the cichofactin biosynthesis } \\
\text { genes to obtain a } 9.7-\mathrm{kb} \text { deletion in these genes }\end{array}$ & This study \\
\hline \multicolumn{3}{|l|}{ Primers $\left(5^{\prime} \rightarrow 3^{\prime}\right)$} \\
\hline NRPS14mut-F1 & $\begin{array}{l}\text { GGAATTGTGAGCGGATAACAATTTCACACAGGAAACAGCTGAGGTGCTG } \\
\text { GTGGACTTCAAT }\end{array}$ & This study \\
\hline NRPS14mut-R1 & ATCGAAACTGACAGGCGTCT GTACCTGACCCGAGGTAGCA & This study \\
\hline NRPS14mut-F2 & TGCTACCTCGGGTCAGGTAC AGACGCCTGTCAGTTTCGAT & This study \\
\hline NRPS14mut-R2 & $\begin{array}{l}\text { CCAGGCAAATTCTGTTTTATCAGACCGCTTCTGCGTTCTGATTGTGTTTC } \\
\text { TGTCTCGCCTTG }\end{array}$ & This study \\
\hline
\end{tabular}

\footnotetext{
${ }^{a}$ Primer extensions are in italic font. $\mathrm{Tc}^{\mathrm{r}}, \mathrm{Km}^{\mathrm{r}}, \mathrm{Sm}^{\mathrm{r}}$, and $\mathrm{Gm}^{\mathrm{r}}$ indicate resistant to tetracycline, kanamycin, streptomycin, and gentamycin, respectively.
} 
(Berti et al. 2007) are the only members of the syringafactin family of linear Pseudomonas-produced lipopeptides. It has been suggested that the syringafactin NRPS system in $P$. syringae evolved from the arthrofactin (a cyclic lipoundecapeptide produced by Pseudomonas sp. MIS38) system, after which three modules of the arthrofactin NRPS were deleted, including the module that incorporates the threonyl residue that forms the ester linkage involved in cyclization. This may explain why syringafactins (and cichofactins) are linear (Berti et al. 2007; Roongsawang et al. 2011).

The genes encoding two nonribosomal peptide synthethases, cifA and cifB, were identified in the genome of $P$. cichorii SF154 as responsible for cichofactin biosynthesis. The putative peptide sequence of cichofactins predicted by in silico analysis of the A domain correlates perfectly with the peptide sequence determined by MS. In the flanking regions of cichofactin biosynthesis clusters, genes coding for ABC transporter systems and LuxR-type regulators have been found (Fig. 3) as previously identified in the lipopeptide biosynthesis genes of many Pseudomonas strains (Berti et al. 2007; de Bruijn and Raaijmakers, 2009; de Bruijn et al. 2008; Dubern et al. 2008; Kang and Gross 2005; Quigley et al. 1993; Roongsawang et al. 2003; Vallet-Gely et al. 2010). In P. syringae pv. tomato DC3000, only the LuxR-type transcriptional regulator upstream of the syringafactin biosynthesis genes appeared to be essential, whereas a mutation of the LuxR-type regulator located downstream did not affect the production of that compound (Berti et al. 2007).

Several biological roles for lipopeptides have been proposed, including their function in motility, antimicrobial activity, biofilm formation, and pathogenicity (D'aes et al. 2010; Raaijmakers et al. 2006, 2010). Little is known about functions of the lipopeptides belonging to the syringafactin family except for the involvement in swarming motility (Berti et al. 2007; Burch et al. 2010, 2012). To clarify the functions of cichofactins in $P$. cichorii SF1-54, a cichofactin-deficient mutant was constructed. This mutant does not produce cichofactins anymore but, surprisingly, an enhanced production of the phytotoxic compounds $\mathrm{G}$ and $\mathrm{F}$ was observed (Fig. 4). A similar phenomenon has been observed in B. subtilis 168 derivative strains which are able to synthesize lipopeptides after integration of a functional sfp gene (Coutte et al. 2010). Disruption of the plipastatin operon enhanced surfactin production. The redirection of common precursors, which needs ATP and cofactors, from the disrupted biosynthetic pathway to the other intact biosynthetic pathway of a lipopeptide may explain this phenomenon (Coutte et al. 2010).

Cichofactins were shown to be essential for surface motility in all $P$. cichorii isolates tested. This role has been established for many surfactants produced by pseudomonads such as syringafactin, entolysin, massetolide, viscosin, putisolvin, and arthrofactin (Berti et al. 2007; de Bruijn et al. 2007, 2008; Kruijt et al. 2009; Kuiper et al. 2004; Roongsawang et al. 2003; Vallet-Gely et al. 2010). Furthermore, microtiter plate assays showed that the cichofactin-deficient mutant formed significantly more biofilm than the wild-type strain $P$. cichorii SF1-54 (Fig. 5B). Several lipopeptides of Pseudomonas have been described to positively or negatively influence biofilm formation. For example, viscosin, massetolide, and CLP1 (sessilin) produced by $P$. fluorescens strains SBW25 and SS101 and Pseudomonas CMR12a, respectively (D'aes et al. 2010; de Bruijn et al. 2007, 2008), have a positive influence on biofilm formation, whereas putisolvins, arthrofactin, and CLP2 (orfamide) produced by $P$. putida, Pseudomonas sp. MIS38, and Pseudomonas CMR12a, respectively (D'aes et al. 2010; Kuiper et al. 2004; Roongsawang et al. 2003), negatively affect biofilm formation.
Cichofactins are also involved in pathogenicity of $P$. cichorii SF1-54 on lettuce but are not phytotoxic per se. Our data suggest that cichofactins are important for the in planta spread of $P$. cichorii because the cichofactin mutant strain spread in lettuce midribs at a significantly slower rate than the wild type. Both cichofactins A and B were detected in infected plant tissue (Fig. 6), indicating their importance in infection or pathogenesis of lettuce leaves by $P$. cichorii. In contrast, the production of the other compounds in infected leaf tissues by P. cichorii SF1-54 remains unclear. They may be produced in very low amounts compared with cichofactins and, thus, in insufficient amounts for adequate detection using HPLC-ESI-MS. This latter hypothesis should not be surprising because syringomycins were detected in infected leaf tissue only in minute amounts by repeated fractionations using HPLC (Grgurina et al. 2002). Another possibility is that they are produced at earlier time points and degrade to low amounts or interact with the plasma membrane or other components of the plant cell (Fogliano et al. 1999; Henry et al. 2011), which may thwart chemical detection.

Interestingly, $P$. cichorii isolates that have low virulence on lettuce produce less cichofactin than more pathogenic isolates (Fig. 7B). It remains to be investigated whether these isolates also differ in their production of the phytotoxic compounds $\mathrm{F}$ and $\mathrm{G}$.

In conclusion, this study showed that $P$. cichorii SF1-54 produces seven bioactive compounds with lipopeptide characteristics, and two new lipopeptides which we focused on were identified as isomers and named cichofactins. Our results provide evidence that cichofactins are responsible for swarming motility and are involved in virulence of $P$. cichorii SF1-54 on lettuce. We are currently investigating the role of compounds $F$ and $G$ in virulence and bioactivity of $P$. cichorii.

\section{MATERIALS AND METHODS}

\section{Microorganisms and culture conditions.}

Microorganisms used in this study are listed in Table 3. P. cichorii isolates and mutants and Escherichia coli strains were kept at $-80^{\circ} \mathrm{C}$ in LB broth (Sambrook and Russel 2001) with $20 \%$ glycerol for long-term storage. $R$. mucilaginosa MUCL 30397, G. candidum MUCL 28959, and B. megaterium LMG 7127 were used as indicator organisms for bioassays of antimicrobial activities. Bacillus and Rhodotorula strains were maintained at $-80^{\circ} \mathrm{C}$ in LB broth with $20 \%$ glycerol, and G. candidum on potato dextrose agar (PDA; Difco, Erembodegem, Belgium) slants. Pseudomonas strains were routinely grown on Pseudomonas Agar F (PAF; Difco) or $\mathrm{SRM}_{\mathrm{AF}}$ medium (Gross 1985). B. megaterium and E. coli strains were grown on $\mathrm{LB}$ medium at 28 and $37^{\circ} \mathrm{C}$, respectively. $R$. mucilaginosa and G. candidum were cultured on PDA at $28^{\circ} \mathrm{C}$. Saccharomyces cerevisiae was grown on yeast-extract-peptone-dextrose medium at $30^{\circ} \mathrm{C}$ (Shanks et al. 2006). Antibiotics were added to the growth media (if required) at the following concentrations: gentamycin at $100 \mu \mathrm{g} / \mathrm{ml}$ and nalidixic acid at $10 \mu \mathrm{g} / \mathrm{ml}$.

\section{Biological activity assays.}

Biosurfactant production was tested using the drop collapse assay, as described by Kuiper and associates (2004). Briefly, cells from a single colony, previously grown on PAF-medium for $24 \mathrm{~h}$, were transferred by a toothpick and suspended into a droplet of $50 \mu \mathrm{l}$ of sterile water on a hydrophobic background (more specifically, parafilm ' $\mathrm{M}$ ' laboratory film). When crude or semipurified culture filtrate or purified compound was tested, $5 \mu \mathrm{l}$ of the material was added to a droplet of $50 \mu \mathrm{l}$ of $\mathrm{H}_{2} \mathrm{O}$ and placed onto parafilm. The reduction in surface tension was visualized by observation of the spread of the droplet over the parafilm surface. 
Biological activity was assayed with $P$. cichorii SF1-54 suspension $\left(1.0 \times 10^{8} \mathrm{CFU} / \mathrm{ml}\right.$ in $50 \mathrm{mM}$ phosphate buffer [PB], $\mathrm{pH}$ 7.0), crude culture filtrate, semipurified culture filtrate, and purified compounds.

Phytotoxic activity was tested on chicory or lettuce leaves by injection of $300 \mu \mathrm{l}$ of bacterial suspension or culture filtrate with a syringe through the abaxial surface. The infiltrated leaves were incubated at $100 \%$ humidity and $25^{\circ} \mathrm{C}$ for $24 \mathrm{~h}$ and appearance of necrotic lesions was scored at $24 \mathrm{~h}$ after injection. $\mathrm{PB}, \mathrm{SRM}_{\mathrm{AF}}$, or methanol were used as negative control treatments.

Antimicrobial activity was tested against B. megaterium, $G$. candidum, and $R$. mucilaginosa using the protocol described by Schaad and associates (2001), with minor modifications. Briefly, a bacterial suspension of $P$. cichorii SF1-54 $\left(1 \times 10^{8}\right.$ $\mathrm{CFU} / \mathrm{ml}$ ) was spotted on PDA plates in triplicate, allowing growth at $25^{\circ} \mathrm{C}$ for 5 days. The areas of colony growth were marked and the colonies removed with a sterile swab. The plates were exposed to chloroform vapors for $20 \mathrm{~min}$ to kill the remaining bacterial cells, followed by dissipation of the vapors for an additional $40 \mathrm{~min}$. When culture filtrate or purified compound was tested, 50 or $10 \mu \mathrm{l}$ was spotted onto PDA plates (for $G$. candidum and $R$. mucilaginosa) or LB plates (for $B$. megaterium), respectively, and followed by drying of the drops. The plate was then sprayed with a spore/cell suspension containing approximately $10^{6}$ cells or spores per milliliter of the indicator organism. After 24 to $48 \mathrm{~h}$ of incubation at $28^{\circ} \mathrm{C}$, inhibition of the indicator organism was scored.

\section{Lipopeptide production, extraction, and purification.}

P. cichorii SF1-54 was grown in 100-ml Erlenmeyer flasks containing $30 \mathrm{ml}$ of $\mathrm{SRM}_{\mathrm{AF}}$ medium. After incubation for 6 days at $25^{\circ} \mathrm{C}$ without shaking, the $P$. cichorii SF1-54 culture was centrifuged $(10,000 \times g, 10 \mathrm{~min})$ (Sigma 4K15; Sartorius, Göttingen, Germany) and the supernatant was filter sterilized through a $0.2-\mu \mathrm{m}$ filter (Millipore; Sartorius) to obtain the crude culture filtrate. Before use, $100 \mu \mathrm{l}$ of this crude culture filtrate was plated on PAF medium in three replications to confirm its sterility. The crude culture filtrate was loaded on $\mathrm{C}_{18}$ solid-phase extraction cartridges (C18 SPE Maxi-Clean cartridges; Alltech, Grace, Lokeren, Belgium) and washed with $5 \%$ methanol, and lipopeptides were desorbed with $100 \mathrm{ml}$ of $100 \%$ methanol to obtain the semipurified culture filtrate.

To purify the $P$. cichorii SF1-54 metabolites, $200 \mathrm{ml}$ of semipurified culture filtrate was further concentrated using rotavaporation (Rotavapor R-2000; Büchi (Essen, Germany) Flawil, Switzerland) and vacuum speed (Savant Speed-Vac Plus SC110A; Thermo Fisher Scientific, Bremen, Germany) and separated with an Agilent 1100 series HPLC (Hewlett Packard, Diegem, Belgium) on a protein and peptide Vydac C18 column (5 $\mu \mathrm{m}, 4.6$ by $250 \mathrm{~mm}$; Grace, Lokeren, Belgium). Metabolites of $P$. cichorii SF1-54 were eluted with a gradient of acetonitrile acidified with $0.1 \%$ formic acid in water acidified with $0.1 \%$ formic acid at a constant flow rate of $1 \mathrm{ml} \mathrm{min}^{-1}$ and at room temperature. The UV signal was monitored at $220 \mathrm{~nm}$. All different fractions were collected, concentrated using rotavaporation and vacuum speed, and used for bioactivity assays.

\section{Chemical analysis of lipopeptides produced by $P$. cichorii SF1-54.}

Amino acid analysis. For the amino acid analysis, HPLCpurified compounds were collected in glass tubes and dried using vacuum speed (Savant Speed-Vac Plus SC110A). The samples were hydrolyzed at $115^{\circ} \mathrm{C}$ for $6 \mathrm{~h}$ with $1.5 \mathrm{ml}$ of $6 \mathrm{~N}$ $\mathrm{HCl}$. After drying in a Speedvac (Savant Speed-Vac Plus SC110A) and dissolving in $100 \mu \mathrm{l}$ of $0.1 \mathrm{~N} \mathrm{HCl}$, the samples were analyzed on a ZORBAX Eclipse AAA column (Agilent,
Diegem, Belgium) using an Agilent 1100 series HPLC (Hewlett Packard) by strictly following the instructions provided by the Agilent manufacturer. Briefly, the hydrolyzed samples and amino acid standard solutions were automatically derivatized in the autosampler with o-phthalaldehyde (OPA) for most amino acids and 9-fluorenylmethyl-chloroformate (FMOC) for lysine, hydroxyproline, and proline residues. After derivatization, $0.5 \mu \mathrm{l}$ of each sample was injected with a flow rate $2 \mathrm{ml} / \mathrm{min}$ and detected at $338 \mathrm{~nm}$ (OPA) and $262 \mathrm{~nm}$ (FMOC). Amino acids in the lipopeptide hydrolysis products were identified and their relative amounts in the samples were estimated based on the amino acid standards analyzed simultaneously.

LC-ESI-MS. Analysis of lipopeptides produced by P. cichorii was carried out with LC-ESI-MS (RP-HPLC Waters Alliance 2695/diode array detector, in tandem with a Single Quad Waters SQD Mass spectrometer; Waters, Zellik, Belgium) on an XTerra MS C18 column $(3.5 \mu \mathrm{m}, 4.6$ by $150 \mathrm{~mm})$ (Waters). Putative lipopeptides of $P$. cichorii SF1-54 were eluted with a gradient of acetonitrile acidified with $0.1 \%$ formic acid in water acidified with $0.1 \%$ formic acid at a constant flow rate $0.5 \mathrm{ml} / \mathrm{min}$ at $40^{\circ} \mathrm{C}$. Compounds were monitored in the positive ion mode and in-source settings in the SQD were as follows: source temperature, $130^{\circ} \mathrm{C}$; desolvation temperature, $280^{\circ} \mathrm{C}$; nitrogen flow, 600 liters/h; cone voltage, $100 \mathrm{~V}$. A similar setting was used for lipopeptide fragmentation, except the cone voltage was $75 \mathrm{~V}$ instead of $100 \mathrm{~V}$. Both instruments were controlled with the MassLynx software (Waters).

$H R$-ESI-MS-MS. All measurements were conducted at the MS lab of the Institute of Organic Chemistry at the University of Cologne on a LTQ-Orbitrap XL instrument (Thermo Fisher Scientific), with a conventional ESI ion source (ESI-voltage, $3.5 \mathrm{kV}$; capillary temperature, $275^{\circ} \mathrm{C}$; and flow rate, $5 \mu \mathrm{l} / \mathrm{min}$ ). Acidified methanol/water solutions were used in micromolar concentrations. $\mathrm{MS}^{\mathrm{n}}$-product ion spectra were produced in a linear ion trap (LTQ part of the Orbitrap) or in an octopole collision cell. The precursor ions were selected and activated until extensive fragmentation occurred.

\section{Identification and bioinformatic analysis of the NRPS genes.}

Whole-genome sequencing of $P$. cichorii SF1-54 was performed at Genoscreen, France, with a Roche 455 Gs-FLX sequencer. The draft genome was automatically annotated using the RAST server (Aziz et al. 2008). Putative NRPS encoding regions were found by comparison of the genome sequence of $P$. cichorii SF1-54 with the genomes of $P$. syringae pv. tomato DC3000 and $P$. syringae pv. syringae B748a (Buell et al. 2003; Feil et al. 2005) using the program MAUVE (Darling et al. 2010). Gap filling in the putative NRPS-encoding gene regions was performed by way of PCR and Sanger sequencing of the PCR product (Agowa Sequencing, Berlin). ORF were identified using the program Glimmer (Delcher et al. 1999), available on the National Center for Biotechnology Information website. The catalytic domains present in the NRPS genes were identified using the NRPS/PKS analysis website (Bachmann and Ravel 2009) and the NRPS-PKS website (Ansari et al. 2004). The specificity prediction of the A domain was conducted by using the web-based software NRPSpredictor2 (Rausch et al. 2005; Rottig et al. 2011). The D/L configurations of amino acid residues of nonribosomal peptide synthetases were investigated by phylogenetic analysis of the $C$ domains via the Phylogeny.fr website (Dereeper et al. 2008). Genes adjacent to the putative NRPS genes were compared with the sequences available in GenBank using the program BlastX. Multiple alignments and phylogeny tree design were performed using the ClustalW2 tool available at the EBI site. 


\section{Construction of the cichofactin-deficient}

\section{P. cichorii SF1-54 mutant.}

A cichofactin-deficient mutant of $P$. cichorii $\mathrm{SF} 1-54 \mathrm{Nal}^{\mathrm{R}}$ was constructed by means of an in vivo cloning technique with the yeast $S$. cerevisiae InvSc1 (Hoang et al. 1998; Shanks et al. 2006). To construct deletion plasmid pMQ30- $\Delta$ cifAB, primers NRPS14mut-F1 and NRPS14mut-R1 were used to amplify the upstream fragment and primers NRPS14mut-F2 and NRPS14mut-R2 were used for the downstream fragment (Table 3). The cichofactin-deficient mutant contained a deletion of 9,715 bp in the cichofactin-encoding genes cifA and cifB. Deletion of the NRPS fragment was confirmed by PCR and the mutant was characterized phenotypically.

\section{Biological roles of cichofactin in $P$. cichorii.}

Surface motility of $P$. cichorii isolates was assayed on soft LB plates $(0.5 \%$ agar). Bacteria of a fully grown colony on PAF-medium were applied in the center of the soft agar plates with a sterile toothpick and the plates were subsequently incubated at $28^{\circ} \mathrm{C}$ up to $72 \mathrm{~h}$ after inoculation.

Biofilm formation was tested in polystyrene 96 -well plates based on protocols described by Merrit and associates (2005) and Maddula and associates (2006), with minor modifications. Briefly, strains were grown overnight in LB broth. The 96-well flat-bottom polystyrene microtiter plates (Greiner bio-one, Wemmel, Belgium) containing $120 \mu \mathrm{l}$ of King's B broth (King et al. 1954) were inoculated using 100-fold dilutions of these culture, previously adjusted to an optical density at $620 \mathrm{~nm}$ $\left(\mathrm{OD}_{620}\right)$ [defined] of 0.8 . Plates were incubated at $21^{\circ} \mathrm{C}$ for 24 $\mathrm{h}$ without shaking and final cell densities were determined $\left(\mathrm{OD}_{620}\right)$. Subsequently, the medium was removed from the microtiter plates, rinsed with water, filled with $150 \mu \mathrm{l}$ of $0.1 \%$ crystal violet, and incubated for $10 \mathrm{~min}$ at room temperature. Excess of stain was removed by inversion of the plate followed by two washings with tap water. When the plates were air dried, adherent cells were decolorized with $95 \%$ ethanol solution for $10 \mathrm{~min}$ and transferred to new microtiter plates in order to measure the absorbance at $595 \mathrm{~nm}$. The experiment was carried out three times, with seven repetitions per treatment. Statistical analysis was performed in SPSS 17.0 (SPSS Inc., Chicago) for Windows using nonparametric Mann-Whitney $\mathrm{U}$ tests $(P=0.05)$.

Pathogenicity of the cichofactin-deficient mutant and of the P. cichorii strains NCPPB 907 and NCPPB $943^{\mathrm{T}}$ was tested at Inagro, Rumbeke, Belgium, according to the methods described in a previous study (Pauwelyn et al. 2011). The strains were inoculated on butterhead lettuce 'Flandria' plants (Rijk Zwaan, De Lier, The Netherlands) at head formation. Tap water without bacteria was used as the noninoculated treatment. Each treatment was assayed in three replicates with 24 plants per replicate and the experiment was carried out twice. At harvest, disease severity was assessed by giving each plant a score of 0 to 4 , where $0=$ healthy plant; $1=$ little black spots on the leaf periphery of the inner crop leaves; $2=$ infection of small side ribs or black spots or stripes on the midrib; $3=$ one, two, or three rotten midribs; and $4=$ four or more rotten midribs. In addition, the number of rotten midribs on each plant was scored. Data were analyzed using nonparametric Kruskal-Wallis and Mann-Whitney comparisons $(P=0.05)$.

To test the ability of $P$. cichorii SF1-54- $\triangle c$ if $A B$ to grow in lettuce midribs, the midrib of the inner lettuce leaves was injected with $0.2 \mathrm{ml}$ of bacterial suspension $\left(1 \times 10^{5} \mathrm{CFU} / \mathrm{ml}\right)$. The injected leaves were incubated at $100 \%$ humidity at $25^{\circ} \mathrm{C}$. The inoculated sections $\left(2 \mathrm{~cm}^{2}\right)$ were excised from the midribs of three lettuce leaves at $0,1,2$, and 3 days postinoculation and macerated in $2 \mathrm{ml}$ of sterile $0.05 \mathrm{M}$ potassium $\mathrm{PB}(\mathrm{pH}$ 7.0). Tenfold serial dilutions from the macerate were prepared with PB and 100- $\mu 1$ aliquots of each dilution were spread on three PAF plates with naladixic acid at $50 \mu \mathrm{g} / \mathrm{ml}$. Colonies were counted 2 days after incubation at $28^{\circ} \mathrm{C}$ to estimate population densities. For assessment of bacterial spread in midribs, the adjacent sections $\left(2 \mathrm{~cm}^{2}\right)$ were also excised from the midribs 3 days postinoculation to estimate population densities as described above. The experiment was repeated twice using three leaves from three different plants per treatment.

Assays for bacterial attachment on lettuce leaves were performed according to the method of Kroupitski and associates (2011), with slight modification. Five leaf discs from different regions (near petiole, center, and near blade) from five different butterhead lettuce leaves were cut using an aseptic cork borer $(1.4 \mathrm{~cm}$ in diameter) and the entire experiment was repeated once. The leaf discs were immersed in $10-\mathrm{ml}$ of a bacterial suspension in a 50-ml falcon tube and incubated at $25^{\circ} \mathrm{C}$ for $2 \mathrm{~h}$ without shaking. The leaf discs were washed twice for $1 \mathrm{~min}$ in $10 \mathrm{ml}$ of sterile water and macerated in $1 \mathrm{ml}$ of sterile $0.05 \mathrm{M}$ potassium $\mathrm{PB}(\mathrm{pH}$ 7.0) for estimation of bacterial population sizes as described before.

All data were statistically analyzed using the software package SPSS 17.0 for Windows. Because the data did not meet the conditions of normality and homogeneity of variance, nonparametric Kruskal-Wallis and Mann-Whitney comparisons $(P=$ $0.05)$ were performed.

\section{In planta detection}

of lipopeptides produced by $P$. cichorii SF1-54.

A bacterial suspension of $P$. cichorii SF1-54 $\left(1 \times 10^{6}\right.$ $\mathrm{CFU} / \mathrm{ml}$ ) was inoculated in the midrib of lettuce leaves. The lettuce leaves were placed on upside-down petri dishes into plastic infection trays filled with wetted sterile cotton. The infection trays were covered with a plastic lid to obtain high relative humidity and incubated at room temperature for 5 days. At 1, 2, 3, 4, and 5 days postinoculation, symptomatic tissue was excised from the lettuce leaves and ground in liquid nitrogen. After thawing, $10 \mathrm{ml}$ of ground symptomatic leaf tissue was suspended in $40 \mathrm{ml}$ of $95 \%$ acetonitrile acidified with $0.1 \%$ formic acid, shaken for $1 \mathrm{~h}$ at room temperature, and then centrifuged ( $5 \mathrm{~min}$ at 10,000 rpm; Beckman avanti J-25i). The pellet was dissolved again in $10 \mathrm{ml}$ of $95 \%$ of acetonitrile acidified with $0.1 \%$ formic acid and centrifuged. Supernatants of both extractions were mixed, concentrated five times using rotavaporation, and analyzed with LC-ESI-MS.

\section{ACKNOWLEDGMENTS}

M. Ongena is Research Associate at the F.R.S.-FNRS in Belgium. This work was financed by the "Fonds voor Wetenschappelijk OnderzoekVlaanderen" (grant number G.0002.10N) and by the INTERREG IV program France-Wallonie-Vlaanderen (Phytobio project). We thank L. Franzil (Gembloux Agro-Bio Tech) and I. Delaere (Ghent University) for technical assistance during the experimental work.

\section{LITERATURE CITED}

Ansari, M. Z., Yadav, G., Gokhale, R. S., and Mohanty, D. 2004. NRPSPKS: a knowledge-based resource for analysis of NRPS/PKS megasynthases. Nucleic Acids Res. 32:405-413.

Aziz, R. K., Bartels, D., Best, A. A., DeJongh, M., Disz, T., Edwards, R. A., Formsma, K., Gerdes, S., Glass, E. M., Kubal, M., Meyer, F., Olsen, G. J., Olson, R., Osterman, A. L., Overbeek, R. A., McNeil, L. K., Paarmann, D., Paczian, T., Parrello, B., Pusch, G. D., Reich, C., Stevens, R., Vassieva, O., Vonstein, V., Wilke, A., and Zagnitko, O. 2008. The RAST server: Rapid annotations using subsystems technology. BMC Genomics 9:75.

Bachmann, B. O., and Ravel, J. 2009. Methods for In silico prediction of microbial secondary metabolic pathways from DNA sequence data. Methods Enzymol. 458:181-217.

Balibar, C. J., Vaillancourt, F. H., and Walsh, C. T. 2005. Generation of D 
amino acid residues in assembly of arthrofactin by dual condensation/epimerization domains. Chem. Biol. 12:1189-1200.

Ballio, A., Barra, D., Bossa, F., Collina, A., Grgurina, I., Marino, G., Moneti, G., Paci, M., Pucci, P., Segre, A., and Simmaco, M. 1991. Syringopeptins, new phytotoxic lipodepsipeptides of Pseudomonas syringae pv. syringae. FEBS (Fed. Eur. Biochem. Soc.) Lett. 291:109-112.

Ballio, A., Bossa, F., Di Giorgio, D., Ferranti, P., Paci, M., Pucci, P., Scaloni, A., Segre, A., and Strobel, G.A.1994. Novel bioactive lipodepsipeptides from Pseudomonas syringae-The pseudomycins. FEBS (Fed. Eur. Biochem. Soc.) Lett. 355:96-100.

Bender, C. L., and Scholz-Schroeder, B. K. 2004. New insights into the biosynthesis, mode of action, and regulation of syringomycin, syringopeptin and coronatine. Kluwer Academic Press, Dordrecht, The Netherlands.

Bender, C. L., Alarcon-Chaidez, F., and Gross, D. C. 1999. Pseudomonas syringae phytotoxins: Mode of action, regulation, and biosynthesis by peptide and polyketide synthetases. Microbiol. Mol. Biol. Rev. 63:266292.

Berti, A. D., Greve, N. J., Christensen, Q. H., and Thomas, M. G. 2007. Identification of a biosynthetic gene cluster and the six associated lipopeptides involved in swarming motility of Pseudomonas syringae pv. tomato DC3000. J. Bacteriol. 189:6312-6323.

Bradbury, J. F. 1986. Guide to Plant Pathogenic Bacteria. Oxford University Press, New York.

Buell, C. R., Joardar, V., Lindeberg, M., Selengut, J., Paulsen, I. T., Gwinn, M. L., Dodson, R. J., Deboy, R. T., Durkin, A. S., Kolonay, J. F., Madupu, R., Daugherty, S., Brinkac, L., Beanan, M. J., Haft, D. H., Nelson, W. C., Davidsen, T., Zafar, N., Zhou, L. W., Liu, J., Yuan, Q. P., Khouri, H., Fedorova, N., Tran, B., Russell, D., Berry, K., Utterback, T., Van Aken, S. E., Feldblyum, T. V., D'Ascenzo, M., Deng, W. L., Ramos, A. R., Alfano, J. R., Cartinhour, S., Chatterjee, A. K., Delaney, T. P., Lazarowitz, S. G., Martin, G. B., Schneider, D. J., Tang, X. Y., Bender, C. L., White, O., Fraser, C. M., and Collmer, A. 2003. The complete genome sequence of the Arabidopsis and tomato pathogen Pseudomonas syringae pv. tomato DC3000. Proc. Natl. Acad. Sci. U.S.A. 100:1018110186.

Burch, A. Y., Shimada, B. K., Browne, P. J., and Lindow, S. E. 2010 Novel high-throughput detection method to assess bacterial surfactant production. Appl. Environ. Microbiol. 76:5363-5372.

Burch, A. Y., Shimada, B. K., Mullin, S. W. A., Dunlap, C. A., Bowman, M. J., and Lindow, S. E. 2012. Pseudomonas syringae coordinates production of a motility-enabling surfactant with flagellar assembly. J. Bacteriol. 194:1287-1298.

Catara, V. 2007. Pseudomonas corrugata: Plant pathogen and/or biological resource? Mol. Plant Pathol. 8:233-244.

Challis, G. L., Ravel, J., and Townsend, C. A. 2000. Predictive, structurebased model of amino acid recognition by nonribosomal peptide synthetase adenylation domains. Chem. Biol. 7:211-224.

Cottyn, B., Heylen, K., Heyrman, J., Vanhouteghem, K., Pauwelyn, E., Bleyaert, P., Van Vaerenbergh, J., Höfte, M., De Vos, P., and Maes, M. 2009. Pseudomonas cichorii as the causal agent of midrib rot, an emerging disease of greenhouse-grown butterhead lettuce in Flanders. Syst. Appl. Microbiol. 32:211-225.

Cottyn, B., Baeyen, S., Pauwelyn, E., Verbaednert, I., De Vos, P., Bleyaert, P., Höfte, M., and Maes, M. 2011. Development of a real-time PCR assay for Pseudomonas cichorii, the causal agent of midrib rot in greenhouse-grown lettuce, and its detection in irrigating water. Plant Pathol. 60:453-461

Coutte, F., Leclère, V., Bechet, M., Guez, J. S., Lecouturier, D., CholletImbert, M., Dhulster, P., and Jacques, P. 2010. Effect of pps disruption and constitutive expression of srfA on surfactin productivity, spreading and antagonistic properties of Bacillus subtilis 168 derivatives. J. Appl. Microbiol. 109:480-491.

D'aes, J., De Maeyer, K., Pauwelyn, E., and Höfte, M. 2010. Biosurfactants in plant-Pseudomonas interactions and their importance to biocontrol. Environ. Microbiol. Rep. 2:359-372.

Danhorn, T., and Fuqua, C. 2007. Biofilm formation by plant-associated bacteria. Annu. Rev. Microbiol. 61:401-422.

Darling, A. E., Mau, B., and Perna, N. T. 2010. progressiveMauve: Multiple genome alignment with gene gain, loss and rearrangement. PloS One 5:e11147. Published online.

de Bruijn, I., and Raaijmakers, J. M. 2009. Diversity and functional analysis of LuxR-type transcriptional regulators of cyclic lipopeptide biosynthesis in Pseudomonas fluorescens. Appl. Environ. Microbiol. 75:47534761

de Bruijn, I., de Kock, M. J. D., Yang, M., de Waard, P., van Beek, T. A., and Raaijmakers, J. M. 2007. Genome-based discovery, structure prediction and functional analysis of cyclic lipopeptide antibiotics in Pseudomonas species. Mol. Microbiol. 63:417-428.

de Bruijn, I., de Kock, M. J. D., de Waard, P., van Beek, T. A., and
Raaijmakers, J. M. 2008. Massetolide a biosynthesis in Pseudomonas fluorescens. J. Bacteriol. 190:2777-2789.

Delcher, A. L., Harmon, D., Kasif, S., White, O., and Salzberg, S. L. 1999. Improved microbial gene identification with GLIMMER. Nucleic Acids Res. 27:4636-4641.

Dereeper, A., Guiqnon, V., Blanc, G., Audic, S., Buffet, S., Chevenet, F. Dufayard, J. F., Guindon, S., Lefort, V., Lescot, M., Claverie, J. M., and Gascuel, O. 2008. Phylogeny.fr: Robust phylogenetic analysis for the non-specialist. Nucleic Acids Res. 36 (Suppl. 2):W465-W469.

Dubern, J. F., Coppoolse, E. R., Stiekema, W. J., and Bloemberg, G. V. 2008. Genetic and functional characterization of the gene cluster directing the biosynthesis of putisolvin I and II in Pseudomonas putida strain PCL1445. Microbiology 154:2070-2083.

Emanuele, M. C., Scaloni, A., Lavermicocca, P., Jacobellis, N. S., Camoni, L., Di Giorgio, D., Pucci, P., Paci, M., Segre, A., and Ballio, A. 1998. Corpeptins, new bioactive lipodepsipeptides from cultures of Pseudomonas corrugata. FEBS (Fed. Eur. Biochem. Soc.) Lett. 433:317-320.

Feil, H., Feil, W. S., Chain, P., Larimer, F., DiBartolo, G., Copeland, A. Lykidis, A., Trong, S., Nolan, M., Goltsman, E., Thiel, J., Malfatti, S., Loper, J. E., Lapidus, A., Detter, J. C., Land, M., Richardson, P. M., Kyrpides, N. C., Ivanova, N., and Lindow, S. E. 2005. Comparison of the complete genome sequences of Pseudomonas syringae pv. syringae B728a and pv. tomato DC3000. Proc. Natl. Acad. Sci. U.S.A. 102:11064-11069.

Flamand, M. C., Pelsser, S., Ewbank, E., and Maraite, H. 1996. Production of syringotoxin and other bioactive peptides by Pseudomonas fuscovaginae. Physiol. Mol. Plant Pathol. 48:217-231.

Fogliano, V., Gallo, M., Vinale, F., Ritieni, A., Randazzo, G., Greco, M., Lops, R., and Graniti, A. 1999. Immunological detection of syringopeptins produced by Pseudomonas syringae pv. lachrymans. Physiol. Mol. Plant Pathol. 55:255-261.

Fuchs, R., and Buzikiewicz, H. 2001. Rearrangement reactions in the electrospray ionization mass spectrometry of pyoverdins. Int. J. Mass Spectrom. 210/211:603-612.

Grgurina, I., Mariotti, F., Fogliano, V., Gallo, M., Scaloni, A., Iacobellis, N. S., Lo Cantore, P., Mannina, L., Castelli, V. V., Greco, M. L., and Graniti, A. 2002. A new syringopeptin produced by bean strains of Pseudomonas syringae pv. syringae. Biochim. Biophys. Acta 1597:8189.

Grgurina, I., Bensaci, M., Pocsfalvi, G., Mannina, L., Cruciani, O., Fiore, A., Fogliano, V., Sorensen, K. N., and Takemoto, J. Y. 2005. Novel cyclic lipodepsipeptide from Pseudomonas syringae pv. lachrymans strain 508 and syringopeptin antimicrobial activities. Antimicrob. Agents Chemother. 49:5037-5045.

Grogan, R. G.,, Misaghi, I. J., Kimble, K. A., Greathead, A. S., Ririe, D. and Bardin, R. 1977. Varnish spot, destructive disease of lettuce in California caused by Pseudomonas cichorii. Phytopathology 67:957-960.

Gross, D. C. 1985. Regulation of syringomycin synthesis in Pseudomonas syringae pv. syringae and defined conditions for its production. J. Appl. Bacteriol. 58:167-174.

Henry, G., Deleu, M., Jourdan, E., Thonart, P., and Ongena, M. 2011. The bacterial lipopeptide surfactin targets the lipid fraction of the plant plasma membrane to trigger immune-related defense responses. Cell. Microbiol. 13:1824-1837.

Hikichi, Y., Suzuki, K., Toyoda, K., Horikoshi, M., Hirooka, T., and Okuno, T. 1998. Successive observation of growth and movement of genetically lux-marked Pseudomonas cichorii and the response of host tissues in the same lettuce leaf. Ann. Phytopathol. Soc. Jpn. 64:519525.

Hildebrand, P. D., Braun, P. G., McRae, K. B., and Lu, X. 1998. Role of the biosurfactant viscosin in broccoli head rot caused by a pectolytic strain of Pseudomonas fluorescens. Can. J. Plant Pathol. 20:296-303.

Hoang, T. T., Karkhoff-Schwiezer, R. R., Kutchma, A. J., and Schweizer, H. P. 1998. A broad-host-range Flp-FRT recombination system for sitespecific excision of chromosomally-located DNA sequences: Application for isolation of unmarked Pseudomonas aeruginosa mutants. Gene 212:77-86.

Hojo, H., Koyanagi, M., Tanaka, M., Kajihara, S., Ohnishi, K., Kiba, A., and Hikichi, Y. 2008. The hrp genes of Pseudomonas cichorii are essential for pathogenicity on eggplant but not on lettuce. Microbiology 154:2920-2928.

Hu, F. P., Young, J. M., and Fletcher, M. J. 1998. Preliminary description of biocidal (syringomycin) activity in fluorescent plant pathogenic Pseudomonas species. J. Appl. Microbiol. 85:365-371.

Hutchison, M. L., and Gross, D. C. 1997. Lipopeptide phytotoxins produced by Pseudomonas syringae pv. syringae: Comparison of the biosurfactant and ion channel-forming activities of syringopeptin and syringomycin. Mol. Plant-Microbe Interact. 10:347-354.

Hutchison, M. L., Tester, M. A., and Gross, D. C. 1995. Role of biosurfactant and ion channel-forming activities of syringomycin in transmem- 
brane ion flux-A model for the mechanism of action in the plantpathogen interaction. Mol. Plant-Microbe Interact. 8:610-620.

Isogai, A., Iguchi, H., Nakayama, J., Kusai, A., Takemoto, J. Y., and Suzuki, A. 1995. Structural analysis of new syringopeptins by tandem massspectrometry Biosci. Biotechnol. Biochem. 59:1374-1376.

Jagger, I. C. 1914. A bacterial leaf spot disease of celery. (Abstr.) Phytopathology 4:395.

Jones, J. B., Raju, B. C., and Engelhard, A. W. 1984. Effects of temperature and leaf wetness on development of bacterial spot of geranium and chrysanthemum incited by Pseudomonas cichorii. Plant Dis. 68:248251

Kajihara, S., Hojo, H., Koyanagi, M., Tanaka, M., Mizumoto, H., Ohnishi, K., Kiba, A., and Hikichi, Y. 2012. Implication of hrpW in virulence of Pseudomonas cichorii. Plant Pathol. 61:355-363.

Kang, H. J., and Gross, D. C. 2005. Characterization of a resistance-nodulation-cell division transporter system associated with the syr-syp genomic island of Pseudomonas syringae pv. syringae. Appl. Environ. Microbiol. 71:5056-5065.

Kiba, A., Sangawa, Y., Ohnishi, K., Yao, N., Park, P., Nakayashiki, H., Tosa, Y., Mayama, S., and Hikichi, Y. 2006. Induction of apoptotic cell death leads to the development of bacterial rot caused by Pseudomonas cichorii. Mol. Plant-Microbe Interact. 19:112-122.

Kiba, A., Lee, K. Y., Ohnishi, K., Park, P., Nakayashiki, H., Tosa, Y., Mayama, S., and Hikichi, Y. 2009. Induction of reactive oxygen generation and functional changes in mitochondria and their involvement in the development of bacterial rot in lettuce caused by Pseudomonas cichorii. Physiol. Mol. Plant Pathol. 74:45-54.

King, E. O., Ward, M. K., and Raney, D. E. 1954. Two simple media for the demonstration of pyocyanin and fluorescein. J. Lab Clin. Med. 44:301-307.

Kroupitski, Y., Pinto, R., Belausov, E., and Sela, S. 2011. Distribution of Salmonella typhimurium in romaine lettuce leaves. Food Microbiol. 28:990-997.

Kruijt, M., Tran, H., and Raaijmakers, J. M. 2009. Functional, genetic and chemical characterization of biosurfactants produced by plant growthpromoting Pseudomonas putida 267. J. Appl. Microbiol. 107:546-556.

Kuiper, I., Lagendijk, E. L., Pickford, R., Derrick, J. P., Lamers, G. E. M., Thomas-Oates, J. E., Lugtenberg, B. J. J., and Bloemberg, G. V. 2004 Characterization of two Pseudomonas putida lipopeptide biosurfactants, putisolvin I and II, which inhibit biofilm formation and break down existing biofilms. Mol. Microbiol. 51:97-113.

Kunkel, B. N., and Zhongying, C. 2006. Virulence of Plant Pathogenic Bacteria. Springer, New York

Lavermicocca, P., Iacobellis, N. S., Simmaco, M., and Graniti, A. 1997. Biological properties and spectrum of activity of Pseudomonas syringae pv. syringae toxins. Physiol. Mol. Plant Pathol. 50:129-140.

Lazzaroni, S., Evidente, A., and Surico, G. 2003. Toxic metabolites and lipopolysaccharides from Pseudomonas cichorii. Kluwer Academic Publishers, Dordrecht, The Netherlands.

Maddula, V., Zhang, Z., Pierson, E. A., and Pierson, L. S. 2006. Quorum sensing and phenazines are involved in biofilm formation by Pseudomonas chlororaphis (aureofaciens) strain 30-84. Microb. Ecol. 52:289301

Merrit, J. H., Kadouri, D. E., and O'Toole, G. A. 2005. Growing and analyzing static biofilms. Pages 1B.1.1-1B.1.17 in: Current Protocols in Microbiology. R. Coico, T. Kowalik, J. Quarles, B. Stevenson, and R. Taylor, eds. John Wiley \& Sons, Chichester, U.K

Pauwelyn, E., Vanhouteghem, K., Cottyn, B., De Vos, P., Maes, M., Bleyaert, P., and Höfte, M. 2011. Epidemiology of Pseudomonas cichorii, the case of lettuce midrib rot. J. Phytopathol. 159:298-305.

Quigley, N. B., Mo, Y. Y., and Gross, D. C. 1993. SyrD is required for syringomycin production by Pseudomonas syringae pathovar syringae and is related to a family of ATP-binding secretion proteins. Mol. Microbiol. 9:787-801

Raaijmakers, J. M., de Bruijn, I., and de Kock, M. J. D. 2006. Cyclic lipopeptide production by plant-associated Pseudomonas spp.: Diver- sity, activity, biosynthesis, and regulation. Mol. Plant-Microbe Interact. 19:699-710.

Raaijmakers, J. M., de Bruijn, I., Nybroe, O., and Ongena, M. 2010. Natural functions of lipopeptides from Bacillus and Pseudomonas: More than surfactants and antibiotics. FEMS (Fed. Eur. Microbiol. Soc.) Microbiol. Rev. 34:1037-1062.

Rausch, C., Weber, T., Kohlbacher, O., Wohlleben, W., and Huson, D. H. 2005. Specificity prediction of adenylation domains in nonribosomal peptide synthetases (NRPS) using transductive support vector machines (TSVM). Nucleic Acids Res. 33:5799-5808.

Rausch, C., Hoof, I., Weber, T., Wohlleben, W., and Huson, D. H. 2007. Phylogenetic analysis of condensation domains in NRPS sheds light on their functional evolution. BMC Evol. Biol. 7:78.

Roongsawang, N., Hase, K., Haruki, M., Imanaka, T., Morikawa, M., and Kanaya, S. 2003. Cloning and characterization of the gene cluster encoding arthrofactin synthetase from Pseudomonas sp. MIS38. Chem. Biol. 10:869-880

Roongsawang, N., Washio, K., and Morikawa, M. 2011. Diversity of nonribosomal peptide synthetases involved in the biosynthesis of lipopeptide biosurfactants. Int. J. Mol. Sci. 12:141-172.

Rottig, M., Medema, M. H., Blin, K., Weber, T., Rausch, C., and Kohlbacher, O. 2011. NRPSpredictor2-a web server for predicting NRPS adenylation domain specificity. Nucleic Acids Res. 39:W362W367.

Sambrook, J., and Russel, D. W. 2001. Molecular Cloning: A Laboratory Manual, 3rd ed. Cold Spring Harbor Laboratory Press, Cold Spring Harbor, NY, U.S.A.

Schaad, N. W., Jones, J. B., and Chun, W. 2001. Laboratory Guide for Identification of Plant Pathogenic Bacteria. American Phytopathological Society Press, St. Paul, MN, U.S.A.

Shanks, R. M. Q., Caiazza, N. C., Hinsa, S. M., Toutain, C. M., and O'Toole, G. A. 2006. Saccharomyces cerevisiae-based molecular tool kit for manipulation of genes from gram-negative bacteria. Appl. Environ. Microbiol. 72:5027-5036.

Simon, R., Priefer, U., and Puhler, A. 1983. A broad host range mobilization system for in vivo genetic engineering: Transposon mutagenesis in gram-negative bacteria. Nat. Biotechnol. 1:784-791.

Turnbull, G. A., Morgan, J. A., Whipps, J. M., and Saunders, J. R. 2001 The role of bacterial motility in the survival and spread of Pseudomonas fluorescens in soil and in the attachment and colonisation of wheat roots. FEMS (Fed. Eur. Microbiol. Soc.) Microbiol. Ecol 36:21-31.

Vallet-Gely, I., Novikov, A., Augusto, L., Liehl, P., Bolbach, G., PechyTarr, M., Cosson, P., Keel, C., Caroff, M., and Lemaitre, B. 2010. Association of hemolytic activity of Pseudomonas entomophila, a versatile soil bacterium, with cyclic lipopeptide production. Appl. Environ. Microbiol. 76:910-921.

Wilk, J. D., and Dye, D. W. 1974. Pseudomonas cichorii causing tomato and celery diseases in New Zealand. N. Z. J. Agric. Res. 17:123-130.

Yamamoto, S., Kasai, H., Arnold, D. L., Jackson, R. W., Vivian, A., and Harayama, S. 2000. Phylogeny of the genus Pseudomonas: Intrageneric structure reconstructed from the nucleotide sequence of $g y r B$ and $r p o D$ genes. Microbiology 146:2385-2394.

Yu, S.-M., and Lee, Y. H. 2012. First report of Pseudomonas cichorii associated with leaf spot on soybean in South Korea. Plant Dis. 96:142.

\section{AUTHOR-RECOMMENDED INTERNET RESOURCES}

NRPS/PKS analysis website: nrps.igs.umaryland.edu/nrps

European Bioinformatics Institute (EBI) website: www.ebi.ac.uk

NRPS-PKS (Nonribosomal Peptide Synthetases and Polyketide Synthases) website: www.nii.res.in/nrps-pks.html

NRPSpredictor2 database: nrps.informatik.uni-tuebingen.de/

University of Wisconsin Madison MAUVE genome alignment software: gel.ahabs.wisc.edu/mauve 